Article

\title{
Life Cycle Greenhouse Gas Analysis of Multiple Vehicle Fuel Pathways in China
}

\author{
Tianduo Peng ${ }^{1,2}$, Sheng Zhou ${ }^{1}$, Zhiyi Yuan ${ }^{1}$ (i) and Xunmin Ou ${ }^{1,2, *}$ \\ 1 Institute of Energy, Environment and Economy, Tsinghua University, Beijing 100084, China; \\ ptd15@mails.tsinghua.edu.cn (T.P.); zhshinet@mail.tsinghua.edu.cn (S.Z.); \\ yuan-zy16@mails.tsinghua.edu.cn (Z.Y.) \\ 2 China Automotive Energy Research Center, Tsinghua University, Beijing 100084, China \\ * Correspondence: ouxm@mail.tsinghua.edu.cn; Tel.: +86-10-6279-2758
}

Received: 1 September 2017; Accepted: 24 November 2017; Published: 26 November 2017

\begin{abstract}
The Tsinghua University Life Cycle Analysis Model (TLCAM) is applied to calculate the life cycle fossil energy consumption and greenhouse gas (GHG) emissions for more than 20 vehicle fuel pathways in China. In addition to conventional gasoline and diesel, these include coal- and gas-based vehicle fuels, and electric vehicle (EV) pathways. The results indicate the following. (1) China's current dependence on coal and relative low-efficiency processes limits the potential for most alternative fuel pathways to decrease energy consumption and emissions; (2) Future low-carbon electricity pathways offer more obvious advantages, with coal-based pathways needing to adopt carbon dioxide capture and storage technology to compete; (3) A well-to-wheels analysis of the fossil energy consumption of vehicles fueled by compressed natural gas and liquefied natural gas (LNG) showed that they are comparable to conventional gasoline vehicles. However, importing rather than domestically producing LNG for vehicle use can decrease domestic GHG emissions by $35 \%$ and $31 \%$ compared with those of conventional gasoline and diesel vehicles, respectively; (4) The manufacturing and recovery of battery and vehicle in the EV analysis has significant impact on the overall ability of EVs to decrease fossil energy consumption and GHG emissions from ICEVs.
\end{abstract}

Keywords: life cycle analysis; carbon footprint; vehicle fuel; energy consumption; greenhouse gas

\section{Introduction}

\subsection{Development of Alternative Vehicle Fuels in China}

Over the past decade, China's vehicle population has experienced rapid increasing. As of 2015, there were more than 172 million vehicles in China, a figure that has been growing at an average annual rate of $24.5 \%$ [1], which is certain to further drive China's growing demand for vehicle fuels. Meanwhile oil supply security, $\mathrm{CO}_{2}$ and other air pollution from fossil fuel consumption have aroused widespread concern. Together, these have contributed to the increased attention focused on alternative fuels to replace conventional gasoline and diesel.

Currently available alternative combustion fuels include natural gas (NG) (such as compressed NG (CNG) and liquefied NG (LNG)), methanol, ethanol, biodiesel, and coal-to-liquid (CtL) derived fuels. Moreover, the development of electric vehicles (EVs) has also impacted the demand for conventional gasoline and diesel [2,3]. However, recent statistics show that, across all vehicle types, developments in alternative fuels have had a limited impact on the overall market. Approximately 29 million tons of conventional gasoline and diesel were replaced by alternative vehicle fuel in 2015, accounting for $10 \%$ of the total amount of gasoline and diesel consumed in that year (the figures for gasoline alone were 16.5 million tons and $14 \%$, respectively) [2-4]. LNG, CTL, and biodiesel are alternatives to conventional diesel fuel, approximately 12.5 million tons of which was replaced by them in $2015,7 \%$ of total diesel 
consumption in that year [2]. NG is the dominant replacement fuel and was responsible for $73 \%$ and $66 \%$ of the substitution of conventional gasoline and diesel fuels, respectively [4,5].

\subsection{Life Cycle Studies of Vehicle Fuels}

Life cycle analysis (LCA) of energy use and greenhouse gas (GHG) emissions has been an important aspect in a comprehensive evaluation of vehicle fuel pathways and has been studied by domestic and foreign scholars who have established specific models for different regions. The Greenhouse gas, Regulated Emissions and Energy use in Transportation (GREET) [6,7] and the Lifecycle Emissions Model (LEM) [8,9] are two of the famous LCA models that have been applied to analyze technical pathways in North America [10-12], Europe [13,14] and other regions [15-17]. The conclusions from such analyses reveal strong regional differences, suggesting that the basic model cannot be simply applied to other areas of the world.

Several publications have focused on LCA in the Chinese context for individual alternative vehicle fuels in recent years [18-27]. In addition, recently published are several comparative analyses between two or more pathways [28-33]. However, owing to a lack of detailed data for many intrinsic operations in the model, many of the conclusions have necessarily been drawn following the extrapolation of experimental data or uncertain future forecasts. Generally, comparative studies between individual pathways are relatively simple with limited analysis of the impact of decision-making in the models. Therefore, the current literature makes it difficult to gather sufficiently comparable research results to make comparisons and reach evidence-based conclusions.

To support the Chinese government's decision-making and to help its departments to establish scientific, long- and short-term vehicle energy strategies, it is urgent to develop an appropriate methodology and computational LCA model that can make comparisons between several vehicle fuel pathways. In recent years, the China Automotive Energy Research Center (CAERC) at Tsinghua University has used the GREET model (which was developed and parameterized for the U.S. energy production chain structure) as a basis for developing the Tsinghua University Life Cycle Analysis Model (TLCAM). The model employs as much localized data as possible to provide comprehensive LCA comparisons between the multiple fuel/vehicle pathways that reflect actual situations in China while using the same modeling platform. The model data are frequently updated to increase their relevance to the current policy-making context. A series of domestic vehicle fuel well-to-wheels (WTW) analyses have been published using TLCAM [23,33-38].

In TLCAM, the primary fossil energy input considers three fuel types: coal, oil, and NG. Nine types of end-use energy are principally analyzed: raw coal, crude oil, raw NG, clean coal, processed NG, diesel, gasoline, fuel oil and electricity. Three key GHGs are considered- $\mathrm{CO}_{2}, \mathrm{CH}_{4}$ and $\mathrm{N}_{2} \mathrm{O}-$ with iterative calculations used to include the upstream contribution to the fossil energy consumption and GHG emissions in the LCA. In this way, TLCAM offers a comprehensive and in-depth understanding of energy consumption and GHG emissions for multiple types of vehicle fuel pathways in China.

\subsection{Aim and Structure of This Paper}

This paper updates the life cycle primary fossil energy consumption and greenhouse gas intensity of end-use energy options in China. TLCAM is used to analyze the life-cycle GHG emissions and primary fossil energy consumption for gasoline, diesel, coal-based, NG-based and EVs.

Section 2 introduces the methodology, with all key data and assumptions for the researched vehicle fuel pathways detailed in Section 3. Section 4 presents the main results, and focuses on decreases in GHG emissions compared with conventional gasoline and diesel vehicles. The section also includes a sensitivity analysis of the carbon footprint of LNG fuel pathways and a detailed investigation of EVs. The final section (Section 5) provides some concluding remarks. 


\section{Methodology}

\subsection{Stages Covered and LCA System Boundary}

Strictly speaking, a LCA analysis of energy consumption and GHG emissions for fuel use comprises two parts: the fuel and the vehicle cycles (Figure 1). In this paper, the system boundary for multiple vehicle fuel pathways only includes fuel cycle. However, the energy consumption and GHG emissions attributed to materials production and transportation, vehicle manufacture, vehicle decommissioning and recycling typically accounts for $10-20 \%$ of the total life cycle values, and the proportion for EV pathway is particularly higher owing to the material used in and the manufacture of system components (e.g., the battery and electric motor). Vehicle cycle also has been paid much attention in recent years. Therefore, while our study mainly focuses on analyzing the fuel pathways, we also extend the boundary to include the vehicle cycle to analyze the GHG emissions of vehicle and battery production.

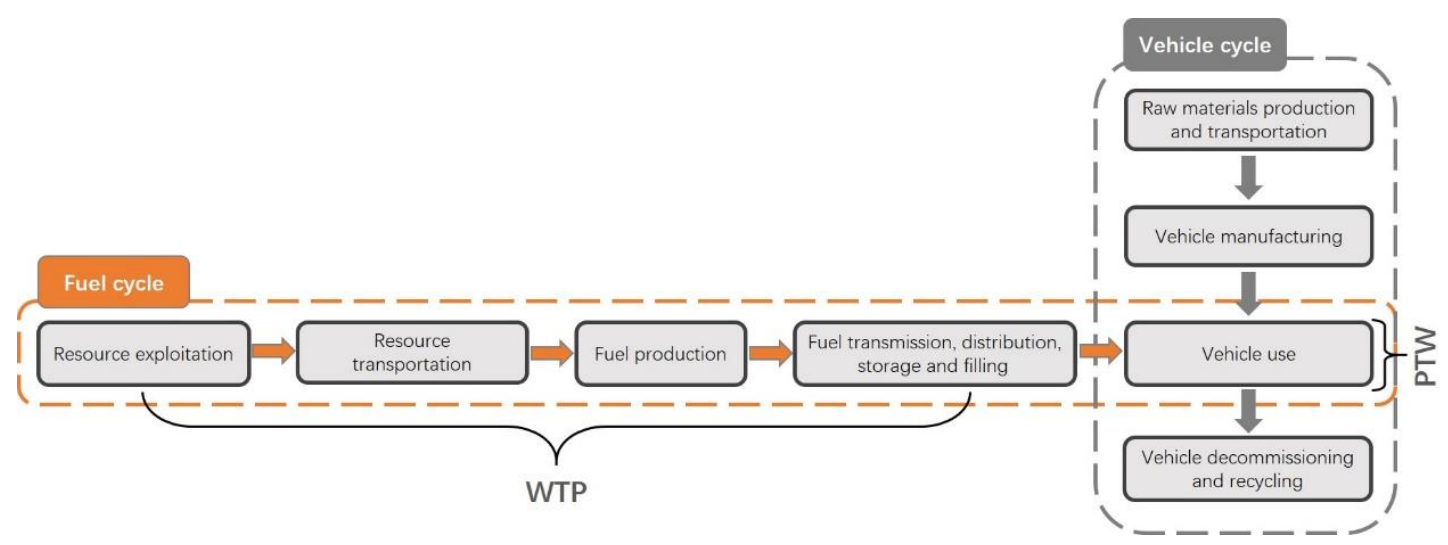

Figure 1. Stages and cycles included in life cycle analysis (LCA) system boundary.

The Well-to-Wheels (WTW) fuel cycle has two stages (as Figure 1 shows). Well-to-Pump (WTP) is the upstream production of the vehicle fuel and includes: resource exploitation and transportation; fuel production, transmission, distribution and storage; and the fuel-filling process. The Pump-to-Wheels (PTW) stage focuses on the fuel combustion and associated emissions from actually using the fuel in a vehicle. The WTW boundary includes the direct use of relevant process and transportation fuel but does not consider indirectly associated energy consumption from plant infrastructure and facilities during their manufacturing or other activities. We used the conventional oil-based pathways as our benchmark transportation fuel pathway. The stages used in the analyses of the other fuels in the study are shown in Table 1 . The functional units are $\mathrm{MJ} / \mathrm{km}$ and $\mathrm{g} \mathrm{CO}_{2, \mathrm{e}} / \mathrm{km}$ for energy consumption and GHG emissions, respectively, based on vehicle distance.

Table 1. Stages included in Well-to-Well (WTW) analysis for different fuel pathways.

\begin{tabular}{|c|c|c|c|c|}
\hline \multicolumn{4}{|c|}{ Well-to-Pump (WTP) } & \multirow{2}{*}{$\begin{array}{c}\begin{array}{c}\text { Pump-to-Wheels } \\
\text { (PTW) }\end{array} \\
\text { Fuel Utilization }\end{array}$} \\
\hline Resource Exploitation & $\begin{array}{c}\text { Resource } \\
\text { Transportation }\end{array}$ & Fuel Production & $\begin{array}{c}\text { Fuel Transmission, } \\
\text { Distribution, Storage } \\
\text { and Filling }\end{array}$ & \\
\hline Crude oil exploitation & $\begin{array}{l}\text { Crude oil } \\
\text { transportation }\end{array}$ & $\begin{array}{l}\text { Refining gasoline, oxygenate } \\
\text { refining, and oxygenated } \\
\text { gasoline preparation } \\
\text { Refining diesel } \\
\text { Refining LPG (Liquefied } \\
\text { Petroleum Gas) }\end{array}$ & $\begin{array}{l}\text { Gasoline transmission } \\
\text { and distribution } \\
\text { Diesel transmission } \\
\text { and distribution } \\
\text { LPG transmission } \\
\text { and distribution }\end{array}$ & $\begin{array}{l}\text { Fuel combustion } \\
\text { in the internal } \\
\text { combustion engine }\end{array}$ \\
\hline
\end{tabular}


Table 1. Cont.

\begin{tabular}{|c|c|c|c|c|}
\hline \multicolumn{4}{|c|}{ Well-to-Pump (WTP) } & \multirow{2}{*}{$\begin{array}{c}\begin{array}{c}\text { Pump-to-Wheels } \\
\text { (PTW) }\end{array} \\
\text { Fuel Utilization }\end{array}$} \\
\hline Resource Exploitation & $\begin{array}{c}\text { Resource } \\
\text { Transportation }\end{array}$ & Fuel Production & $\begin{array}{l}\text { Fuel Transmission, } \\
\text { Distribution, Storage } \\
\text { and Filling }\end{array}$ & \\
\hline $\begin{array}{l}\text { Coal mining, processing } \\
\text { and washing }\end{array}$ & Coal transportation & $\begin{array}{l}\text { Coal gasification and } \\
\text { synthesis of methanol } \\
\text { Coal gasification and } \\
\text { synthesis of DME } \\
\text { (Dimethyl Ether) } \\
\text { Production of CtL } \\
\text { (Coal to Liquid) }\end{array}$ & $\begin{array}{l}\text { Methanol transmission } \\
\text { and distribution } \\
\text { DME transmission } \\
\text { and distribution } \\
\text { CtL transmission } \\
\text { and distribution }\end{array}$ & \\
\hline $\begin{array}{l}\text { Gas exploitation } \\
\text { and purification }\end{array}$ & NG transportation & $\begin{array}{l}\text { NG compression } \\
\text { NG liquefaction } \\
\text { GTL (Gas to } \\
\text { Liquid) production }\end{array}$ & $\begin{array}{l}\text { CNG transmission } \\
\text { and distribution } \\
\text { LNG transmission } \\
\text { and distribution } \\
\text { GTL transmission } \\
\text { and tdistribution }\end{array}$ & \\
\hline $\begin{array}{l}\text { Crude oil, NG, coal, } \\
\text { and other raw } \\
\text { materials exploitation } \\
\text { and processing }\end{array}$ & $\begin{array}{l}\text { Transportation of } \\
\text { raw materials }\end{array}$ & $\begin{array}{l}\text { Raw material } \\
\text { electricity generation }\end{array}$ & $\begin{array}{l}\text { Electricity transport, } \\
\text { distribution and } \\
\text { battery charging }\end{array}$ & Driving electric motor \\
\hline
\end{tabular}

\subsection{Calculation of Life Cycle Factors for End-Use Energy}

In TLCAM, an end-use energy's life cycle fossil energy intensity is defined as the total primary fossil energy consumption required to obtain and use $1 \mathrm{MJ}$ of the end-use energy. We then defined the life cycle GHG emissions intensity as the GHG emissions associated with the production and use of $1 \mathrm{MJ}$ of the end-use energy. Life cycle factors were calculated by the model using an automated iterative method [34]. Fuller details on the calculation methodology and the main data used are presented in the Appendix A.

\subsection{Calculation Methods for Life Cycle Intensity for Vehicle Fuel Pathways}

The life cycle fossil energy intensity (MJ/MJ) and GHG emissions intensity ( $\mathrm{g} \mathrm{CO}_{2, \mathrm{e}} / \mathrm{MJ}$ ) of a specific vehicle fuel pathway were calculated as the sum of all end-use energy consumed across all of the WTW stages multiplied by the life cycle factors of these end-use energies as a process fuel. For vehicle fuel derived from oil, NG and coal sources, the analysis of the intensity of energy and GHG emissions contained two categories: (1) the intensity related to the direct use of the end-use energy (as, for example, in the diesel and gasoline pathways) which was calculated by TLCAM; and (2) taking a given end-use energy as a starting point, we calculated the sum of the total end-use energy consumption and composition for the subsequent production and transport sub-stages. This second stage involved multiplying and summing the corresponding process intensity factors and was used with pathways involving LPG, CNG, GTL, coal-based liquid fuels, and fossil energy electricity generation.

For a given vehicle fuel pathway, we assumed the pathway had $n$ sub-stages (i.e., $p=1,2, \ldots, n$ ) before the fuel was supplied for vehicle use. As Equation (1) shows, the fossil energy intensity was then calculated as the sum of the products of the nine end-use energies (i.e., $j=1,2, \ldots, 9$ ) that were consumed in the various sub-stages (i.e., $p=1,2, \ldots, n$ ) and the associated life cycle energy intensity:

$$
E_{L C}=\sum_{p=1}^{n} \sum_{j=1}^{9} \sum_{i=1}^{3}\left(E N_{p, j} E F_{L C, j, i}\right)
$$

where $E_{L C}$ is the life cycle fossil energy intensity (MJ/MJ) of a given vehicle fuel pathway; $E F_{L C, j, i}$ (MJ/MJ) is the life cycle fossil energy type $i$ intensity of end-use energy type $j$, which is taken from TLCAM's calculated end-use energy intensity inventory, as described in the Appendix A; and $E N_{p, j}$ 
(MJ/MJ) is the end-use energy type $j$ that is consumed in sub-stage $p$. To carry out the calculation, we then obtained the total end-use energy consumption (or energy efficiency) for each sub-stage to acquire $E N_{p, j}$.

For example, for a given CTL pathway, the fossil energy intensity was calculated using the following equations:

$$
\begin{gathered}
E_{L C}=\sum_{i=1}^{3}\left(E N_{\text {plant }, 4} E F_{L C, 4, i}+E N_{\text {plant }, 9} E F_{L C, 9, i}+\sum_{j=1}^{4}\left(E N_{\text {transport }, j} E F_{L C, j, i}\right)\right) \\
E N_{\text {plant }, 4}=S H_{\text {plant }, 4} / \eta_{\text {plant }} \\
E N_{\text {plant }, 9}=\left(1-S H_{\text {plant }, 4}\right) / \eta_{\text {plant }}
\end{gathered}
$$

where $E N_{\text {plant }, 4}(\mathrm{MJ} / \mathrm{MJ})$ represents the coal consumed by the chemical plant per MJ of liquid fuel produced; $E N_{\text {plant }, 9}(\mathrm{MJ} / \mathrm{MJ})$ is the coal consumed to produce the electricity used to produce $1 \mathrm{MJ}$ of liquid fuel; $E N_{\text {transport }, j}(\mathrm{MJ} / \mathrm{MJ})$ is the amount of end-use energy $j$ consumed during the transport of $1 \mathrm{MJ}$ of liquid fuel; $S H_{\text {plant, }}$ is the proportion of coal in the coal chemical plant's total energy consumption; and $\eta_{\text {plant }}$ is the plant's overall energy efficiency.

For electricity pathways, losses during electricity transmission should be considered. For example, for the coal-powered electricity pathway, the calculation of the heat-value-based fossil energy intensity was carried out as follows:

$$
\begin{gathered}
E_{L C}=\sum_{i=1}^{3}\left(E N_{\text {plant }, 4} E F_{L C, 4, i}\right) \\
E N_{\text {plant }, 4}=1 /\left(\eta_{\text {plant }}\left(1-R_{\text {trans }}\right)\right)
\end{gathered}
$$

where $R_{\text {trans }}$ represents the losses during electricity transmission.

Life cycle GHG emissions were calculated using the $\mathrm{CO}_{2}$-equivalent global warming potentials to directly sum the three main GHG emission intensities $\left(\mathrm{CO}_{2}, \mathrm{CH}_{4}\right.$ and $\left.\mathrm{N}_{2} \mathrm{O}\right)[39,40]$ :

$$
G H G_{L C}=C_{2, L C}+25 C H_{4, L C}+298 N_{2} O_{L C}
$$

Each of the GHG emission intensities $\left(\mathrm{CO}_{2, L C}, \mathrm{CH}_{4, L C}\right.$ and $\left.\mathrm{N}_{2} \mathrm{O}_{L C}\right)$ was determined by summing the product of the end-use energy and the corresponding GHG emission intensity for each sub-stage $\left(\mathrm{CO}_{2, L C, j}, \mathrm{CH}_{4, L C, j}\right.$ and $\left.\mathrm{N}_{2} \mathrm{O}_{L C, j}\right)$ :

$$
\begin{aligned}
& C O_{2, L C}=\sum_{p=1}^{n} \sum_{j=1}^{9}\left(E N_{p, j} C O_{2, L C, j}\right) \\
& C H_{4, L C}=\sum_{p=1}^{n} \sum_{j=1}^{9}\left(E N_{p, j} C H_{4, L C, j}\right) \\
& N_{2} O_{L C}=\sum_{p=1}^{n} \sum_{j=1}^{9}\left(E N_{p, j} N_{2} O_{L C, j}\right)
\end{aligned}
$$

For grid electricity, weighting was attributed to the different electricity pathways, $W_{q}(q=1,2 \ldots$,$) .$ The energy intensity and GHG emission intensity of grid electricity was then calculated as follows:

$$
\begin{aligned}
E_{L C} & =\sum_{q}\left(W_{q} E_{L C, q}\right) \\
G H G_{L C} & =\sum_{q}\left(W_{q} G H G_{L C, q}\right)
\end{aligned}
$$


where $E F_{L C, q}(\mathrm{MJ} / \mathrm{MJ})$ is the life cycle fossil energy intensity and $G H G_{L C, q}\left(\mathrm{~g} \mathrm{CO}_{2}\right.$, e $\left./ \mathrm{MJ}\right)$ is the life cycle GHG emissions intensity of the electricity pathway $q$.

\subsection{Life Cycle Energy Use and GHG Emissions per $\mathrm{km}$}

When the vehicle efficiencies were taken into consideration, through multiplying the life cycle results of each fuel pathway by fuel efficiency, $F E(\mathrm{~km} / \mathrm{MJ})$, we calculated the life cycle fossil energy input, $E_{L C \text {,dist }}(\mathrm{MJ} / \mathrm{km})$, and the GHG emissions, $G H G_{L C \text {,dist }}\left(\mathrm{g} \mathrm{CO}_{2, \mathrm{e}} / \mathrm{km}\right)$, per $\mathrm{km}$ of distance driven by the vehicle.

$$
\begin{aligned}
E_{L C, \text { dist }} & =E F_{L C} F E \\
G H G_{L C, \text { dist }} & =G H G_{L C} F E
\end{aligned}
$$

\section{Data and Assumptions}

\subsection{Basic Data and Parameters}

The main data for the calculation of $E F_{L C}$ and $G H G_{L C}$ for the nine end-use energy options are listed in Appendix A. Table A2 presents original, China-specific data for oil-, NG-, and coal-based fuels and electricity. It includes energy conversion efficiencies, transport distances and the proportion of the different process fuels used in the various resource exploitation, transport, fuel processing and fuel production stages. The energy intensity and breakdown of fuels used by various transport modes are shown in Table A3. Together with the transport fuels' lower heating values (MJ/kg), these data were then used to calculate the process fuel consumption to transport $1 \mathrm{MJ}$ of feedstock or fuel to the end user. Direct and indirect GHG emissions released from the use of various energies in the Chinese context are shown in Table A4. Data on carbon content $\left(\mathrm{CC}_{\mathrm{j}}, \mathrm{g} / \mathrm{MJ}\right)$, fuel oxidation rate $\left(\mathrm{FOR}_{\mathrm{j}}, \mathrm{g} / \mathrm{MJ}\right)$, and the direct $\mathrm{CH}_{4}\left(\mathrm{CH}_{4, \text { direct }}, \mathrm{g} / \mathrm{MJ}\right)$ and $\mathrm{N}_{2} \mathrm{O}\left(\mathrm{N}_{2} \mathrm{O}_{\text {direct }}, \mathrm{g} / \mathrm{MJ}\right)$ emission factors were taken from authoritative literature [33-39]. Indirect $\mathrm{CH}_{4}$ emissions from non-combustion sources, including spills and losses during the resource extraction stage, were calculated using TLCAM.

\subsection{Oil-Based Fuel Pathways}

Imported and domestically produced crude oil needs to be transported to refineries across the country for refining. Refining oil products is a poly-generation process, and therefore it is necessary to proportion the distribution of energy consumption by the process among the various products. Average energy efficiency assumptions were based on a literature review. The energy efficiency of gasoline and diesel is shown in Table A2, and an energy efficiency of LPG plant was assumed to be $90.3 \%$ according to [41]. This value is unlikely to change substantially, even in the long term. For the energy consumption structure shown in Table A2, end-use energy consumption data for oil processing, coal coking and nuclear fuel processing was taken from the China Energy Statistical Yearbook 2016 [42].

Data relating to the transmission and distribution of gasoline, diesel and fuel oil is shown in Table A1. Similar data for LPG are shown in Table 2.

Table 2. LPG transmission and distribution parameters [34].

\begin{tabular}{cccccc}
\hline Modes of Transport & Ocean & Railway & Pipeline & Water & Highway \\
\hline Proportion $(\%)$ & 30 & 80 & 0 & 15 & 10 \\
Average transport distance $(\mathrm{km})$ & 7000 & 900 & 0 & 1200 & 50 \\
\hline Note: The sum of the proportions of individual transport modes may exceed $100 \%$.
\end{tabular}

\subsection{NG-Based Fuel Pathways}

The main component of NG is the GHG methane $\left(\mathrm{CH}_{4}\right)$. Leakage during the exploitation and processing of NG can have powerful GHG emission effects, potentially affecting the overall pathway's 
energy savings and associated decrease in GHG emissions. The amount of fugitive $\mathrm{CH}_{4}$ during NG exploitation activities was assumed to be $0.34 \%$.

Table 3 shows the energy efficiencies for the CNG, LNG and GTL pathways. LNG was divided into three types: imported LNG (LNG 1); LNG that was liquefied near to a domestic gas field (LNG 2); and liquefaction of NG post-transported via pipelines in China (LNG 3).

Table 3. Energy efficiencies for the different NG-based fuel pathways $[7,23]$.

\begin{tabular}{ccc}
\hline NG-Based Fuel & Energy Efficiency (\%) & Process Fuel Mix \\
\hline CNG & $96.9 \%$ & NG (97\%) and electricity (3\%) \\
LNG 1 & $91.0 \%$ & NG $(98 \%)$ and electricity $(2 \%)$ \\
LNG 2 & $95.19 \%$ & Electricity $(100 \%)$ \\
LNG 3 & $95.19 \%$ & Electricity $(100 \%)$ \\
GTL & $54.20 \%$ & NG $(100 \%)$ \\
\hline
\end{tabular}

Parameters relating to the transmission and distribution of CNG, LNG and GTL are listed in Table 4. The WTW analysis of NG-based vehicle fuels is sensitive to the distance and mode by which NG is transported, which necessitated careful setting of these parameters. Given that CNG vehicles are mainly used in regions with rich NG resources, we assumed that the NG transport distance for CNG production was $300 \mathrm{~km}$. CNG is directly used by vehicles, meaning that there was no further transmission and distribution included in the model. For LNG 1, after $6700 \mathrm{~km}$ of transport by ship, the LNG was assumed to be used after a short-distance transmission and distribution system. LNG 2 was directly liquefied at a domestic gas field and then transported by road for use. LNG 3 was transported via pipelines $(1500 \mathrm{~km})$, then liquefied and injected into a transmission and distribution system that was assumed to cover an average distance of $100 \mathrm{~km}$. Plants producing GTL and other liquid fuels are always constructed near gas fields in China, so we assumed that NG was transported $100 \mathrm{~km}$ to the plant via a pipeline from the gas field. The transmission and distribution modes of GTL were then assumed to be the same as those of conventional diesel.

Table 4. Transmission and distribution parameters for NG-based fuels [23].

\begin{tabular}{cl}
\hline NG-Based Fuel & \multicolumn{1}{c}{ Transport Mode } \\
\hline CNG & -- \\
LNG 1 & Waterway: $100 \%(6700 \mathrm{~km})$, Road vehicle: $100 \%(100 \mathrm{~km})$ \\
LNG 2 & Road vehicle: $100 \%(100 \mathrm{~km})$ \\
LNG 3 & Road vehicle: $100 \%(100 \mathrm{~km})$ \\
GTL & Railway: $50 \%(900 \mathrm{~km}) ;$ pipeline: $15 \%(160 \mathrm{~km}) ;$ waterway: \\
& $10 \%(1200 \mathrm{~km}) ;$ road (short distance): $10 \%(50 \mathrm{~km})$ \\
\hline
\end{tabular}

\subsection{Coal-Based Fuel Pathways}

Four CtL vehicle fuel pathways were included: methanol blended into vehicle gasoline; dimethyl ether (DME); and the direct and indirect production of synthetic oil productions from coal liquefaction. Many domestic plants, with varying energy efficiencies and fuel mixes, currently produce such fuels using coal as the raw material. For the direct $\mathrm{CtL}$ and indirect $\mathrm{CtL}$ (ICtL) pathways, we assumed that no extra electricity was needed, besides that supplied by the production plant's in-house electricity generation units. Details of the relevant assumptions are listed in Table 5. 
Table 5. Energy efficiencies and process fuels for fuels produced via different CTL processes [33,41].

\begin{tabular}{ccc}
\hline Coal-Based Product & Energy Efficiency & Process Fuel Mix \\
\hline Coal-based methanol & $50.22 \%$ & Coal (91\%) and electricity $(9 \%)$ \\
Coal-based DME & $47.46 \%$ & Coal $(93 \%)$ and electricity $(7 \%)$ \\
Direct CtL & $49.30 \%$ & Coal $(100 \%)$ \\
Indirect CtL & $41.41 \%$ & Coal $(100 \%)$ \\
\hline
\end{tabular}

Different modes of transport can be employed for coal consumed in electricity production or in the production of coal-based vehicle fuels. Generally, such production plants are built near coal mines. Thus, based on existing plants, coal was assumed to be transported for $30 \mathrm{~km}$ by truck to reach the coal field from coal mines, and then $20 \mathrm{~km}$ by truck to reach the plants from coal field. Subsequent transmission and distribution of ethanol, DME, and coal-based liquid fuels were then assumed to be the same as for conventional diesel (Table A2).

\subsection{Electricity Pathways}

Relevant data for coal-, oil- and NG-based thermal electricity pathways are listed in Table A2. Hydro, nuclear, solar, biomass, and other forms of electricity generation also account for a sizable proportion of China's electricity supply. As shown in Table 6, the fossil energy consumption by hydro, wind, and solar electricity is negligible $[33,43,44]$. However, emissions associated with facility construction and decommissioning should not be omitted. Especially for hydroelectricity, the creation of the reservoir can cause $\mathrm{CO}_{2}, \mathrm{CH}_{4}$ and other $\mathrm{GHG}$ emissions related to the biological degradation of vegetation. The life cycle emission factors of these power-generating options were approximated as $5 \mathrm{~g} \mathrm{CO}_{2, \mathrm{e}} / \mathrm{MJ}$.

Table 6. Life cycle energy-use intensity and GHG-emissions intensity of non-fossil electricitygenerating pathways.

\begin{tabular}{cccc}
\hline Electricity Type & Fossil Energy Use (MJ/MJ) & GHG Emissions $\left(\mathrm{g} \mathrm{CO}_{2, \mathrm{e}} / \mathbf{M J}\right)$ & Data Source \\
\hline Nuclear & 0.063 & 6.506 & {$[33]$} \\
Biomass & 0.076 & 5.846 & {$[43]$} \\
Hydro and Others & 0 & 5 & {$[44]$} \\
\hline
\end{tabular}

\subsection{Carbon Dioxide Capture and Storage (CCS) Technology}

Studies on the application of CCS technology for coal-burning plants suggest that an extra 80-160 kWh of electricity is required per ton of compressed $\mathrm{CO}_{2}$ obtained at a $\mathrm{CO}_{2}$ capture rate of approximately $90 \%$ [41,45-47]. We therefore assumed a figure of $140 \mathrm{kWh} / \mathrm{t} \mathrm{CO}$, which corresponded to a decrease in the plant's efficiency of $10 \%$ (for example from $40 \%$ to $30 \%$ ). For the $\mathrm{CO}_{2}$ transport and storage stages, we assumed that energy consumption was negligible when compared with that of the capture stage.

\subsection{Vehicle Size and Fuel Efficiency}

The fuel economy of a mid-sized passenger vehicle was assumed to be $8 \mathrm{~L}$ of gasoline per $100 \mathrm{~km}$. Taking the internal combustion engine (ICE) gasoline vehicle as the base case here, comparisons were then made by employing the fuel economy values of other combinations of vehicles and fuel production pathways (Table 7). WTW analysis results for various vehicle technologies were then calculated and compared for different fuels on a per $\mathrm{km}$ basis. 
Table 7. PTW efficiency for various vehicle fuels in China [33,35,48].

\begin{tabular}{cccc}
\hline Vehicle Fuel Type & $\begin{array}{c}\text { Vehicle Power } \\
\text { Technology Type }\end{array}$ & $\begin{array}{c}\text { Running Distance per } \\
\text { Unit of Energy (\%) } \\
\text { (Base }=\mathbf{1 0 0} \%)\end{array}$ & $\begin{array}{c}\text { Energy Consumption } \\
\text { per Unit of Distance } \\
\text { (Base = 1.00) }\end{array}$ \\
\hline Gasoline & ICE & 100.0 & 1.00 \\
Diesel & ICE & 109.9 & 0.91 \\
LPG & ICE & 95.2 & 1.05 \\
CNG & ICE & 95.2 & 1.05 \\
LNG & ICE & 99.7 & 1.00 \\
GTL & ICE & 120.0 & 0.83 \\
Ethanol & ICE & 100.0 & 1.00 \\
Methanol & ICE & 100.0 & 1.00 \\
DME & ICE & 105.0 & 0.95 \\
Biodiesel & ICE & 109.9 & 0.91 \\
Direct CtL & ICE & 117.6 & 0.85 \\
Indirect CtL & ICE & 98.0 & 1.02 \\
Electricity & Electromotor & 351.0 & 0.28 \\
\hline
\end{tabular}

\section{Results and Discussion}

\subsection{Life Cycle Primary Fossil Energy and Carbon Intensity of End-Use Energy in China}

TLCAM model was used to recalculate and update the life cycle fossil energy and GHG emissions intensities of China's major end-use energy options for 2015, as shown in Table 8.

Table 8. Calculated life cycle fossil energy and GHG emissions intensities for China in 2015.

\begin{tabular}{|c|c|c|c|c|c|c|c|c|}
\hline Item & $\mathrm{EF}_{\mathrm{LC}}$ & $\mathrm{EF}_{\mathrm{LC}, \mathrm{Coal}}$ & $\mathrm{EF}_{\mathrm{LC}, \mathrm{NG}}$ & $\mathrm{EF}_{\mathrm{LC}, \mathrm{Oil}}$ & $\mathrm{GHG}_{\mathrm{LC}}$ & $\mathrm{CO}_{2, \mathrm{up}}$ & $\mathrm{CH}_{4, \mathrm{up}}$ & $\mathrm{N}_{2} \mathrm{O}_{\text {up }}$ \\
\hline Unit & $\mathrm{MJ} / \mathrm{MJ}$ & $\mathrm{MJ} / \mathrm{MJ}$ & MJ/MJ & MJ/MJ & $\mathrm{gCO}_{2, \mathrm{e}} / \mathrm{MJ}$ & $\mathrm{g} / \mathrm{MJ}$ & g/MJ & $\mathrm{mg} / \mathrm{MJ}$ \\
\hline Raw coal & 1.071 & 1.068 & 0.001 & 0.002 & 98.3 & 5.776 & 0.434 & 0.127 \\
\hline Raw NG & 1.141 & 0.041 & 1.052 & 0.048 & 67.5 & 9.660 & 0.093 & 0.403 \\
\hline Crude oil & 1.097 & 0.028 & 0.036 & 1.033 & 79.2 & 6.692 & 0.024 & 0.279 \\
\hline Clean coal & 1.086 & 1.070 & 0.002 & 0.014 & 99.4 & 6.846 & 0.435 & 0.377 \\
\hline processed NG & 1.145 & 0.041 & 1.056 & 0.048 & 69.3 & 9.934 & 0.093 & 0.409 \\
\hline Diesel & 1.259 & 0.066 & 0.047 & 1.146 & 92.3 & 18.575 & 0.041 & 0.406 \\
\hline Gasoline & 1.268 & 0.068 & 0.047 & 1.153 & 90.2 & 19.216 & 0.042 & 0.411 \\
\hline Fuel oil & 1.197 & 0.052 & 0.042 & 1.102 & 90.8 & 14.022 & 0.034 & 0.360 \\
\hline Electricity & 2.250 & 2.140 & 0.075 & 0.035 & 203.4 & 181.507 & 0.877 & 2.848 \\
\hline
\end{tabular}

\subsection{Life Cycle Primary Energy Use of Multiple Vehicle Fuels}

The primary energy consumption (total WTW fossil energy input) and energy conversion efficiency (the ratio between the heat value of the end-use fuel and WTW fossil energy input) for the various vehicle fuel pathways calculated by TLCAM are presented in Table 9. We found that oil- and NG-based gaseous fuels consumed similar amounts of primary fossil energy, from 1.198 to $1.282 \mathrm{MJ} / \mathrm{MJ}$, with energy conversion efficiencies from $77.97 \%$ to $83.49 \%$. GTL and coal-based fuel pathways ranked behind those based on oil with primary fossil energy inputs ranging from 2.141 to $2.629 \mathrm{MJ} / \mathrm{MJ}$ and energy conversion efficiencies from $38.03 \%$ to $46.71 \%$. With application of CCS technology, the WTW fossil energy consumption of coal-based fuel pathways increased further (2.532-3.298 MJ/MJ), further decreasing the energy conversion efficiencies (30.32-39.49\%). For the electricity pathways, at 4.030 MJ/MJ, the WTW fossil energy consumption input was particularly high for oil-fired electricity generation, with a conversion efficiency of just $24.81 \%$. By contrast the WTW fossil energy consumption for nuclear- and biomass-powered electricity generation pathways were low, and negligible for that employing hydropower. The fossil energy consumption for the averaged grid electricity pathway was 2.250 MJ/MJ, reflecting the various sources of electricity that make up the grid's electricity supply. The average energy conversion efficiency was $44.45 \%$. 
The primary fossil consumption results indicate that non-oil-based pathways can achieve a significant "oil-substitution effect" from a WTW life cycle point of view.

Table 9. Primary energy consumption and energy conversion efficiency of vehicle fuel pathways.

\begin{tabular}{|c|c|c|c|c|c|}
\hline \multirow[b]{2}{*}{ Pathway } & \multicolumn{4}{|c|}{ Energy Consumption (MJ/MJ) } & \multirow{2}{*}{$\begin{array}{c}\text { Energy } \\
\text { Conversion } \\
\text { Efficiency (\%) }\end{array}$} \\
\hline & $\begin{array}{c}\text { Coal } \\
\text { Consumption }\end{array}$ & $\begin{array}{c}\text { Oil } \\
\text { Consumption }\end{array}$ & $\begin{array}{c}\text { NG } \\
\text { Consumption }\end{array}$ & $\begin{array}{c}\text { Total } \\
\text { Consumption }\end{array}$ & \\
\hline Gasoline & 0.072 & 0.052 & 1.158 & 1.282 & 77.98 \\
\hline Diesel & 0.070 & 0.051 & 1.151 & 1.273 & 78.57 \\
\hline LPG & 0.049 & 0.047 & 1.161 & 1.257 & 79.57 \\
\hline CNG & 0.071 & 1.120 & 0.006 & 1.198 & 83.49 \\
\hline LNG1 & 0.015 & 1.228 & 0.040 & 1.282 & 77.97 \\
\hline LNG2 & 0.113 & 1.118 & 0.013 & 1.244 & 80.37 \\
\hline LNG3 & 0.116 & 1.129 & 0.014 & 1.259 & 79.44 \\
\hline GTL & 0.043 & 2.046 & 0.052 & 2.141 & 46.71 \\
\hline Coal-based methanol & 2.297 & 0.012 & 0.049 & 2.358 & 42.40 \\
\hline Coal-based DME & 2.417 & 0.011 & 0.053 & 2.480 & 40.32 \\
\hline $\mathrm{CtL}$ & 2.172 & 0.004 & 0.034 & 2.210 & 45.25 \\
\hline ICtL & 2.586 & 0.004 & 0.039 & 2.629 & 38.03 \\
\hline Coal-based methanol + CCS & 2.720 & 0.018 & 0.060 & 2.797 & 35.75 \\
\hline Coal-based DME + CCS & 2.853 & 0.017 & 0.063 & 2.933 & 34.09 \\
\hline $\mathrm{CtL}+\mathrm{CCS}$ & 2.490 & 0.004 & 0.038 & 2.532 & 39.49 \\
\hline $\mathrm{ICtL}+\mathrm{CCS}$ & 3.244 & 0.005 & 0.048 & 3.298 & 30.32 \\
\hline Grid electricity & 2.140 & 0.075 & 0.035 & 2.250 & 44.45 \\
\hline Coal electricity & 3.147 & 0.005 & 0.042 & 3.194 & 31.31 \\
\hline Oil electricity & 0.184 & 0.150 & 3.696 & 4.030 & 24.81 \\
\hline Gas electricity & 0.017 & 2.625 & 0.013 & 2.656 & 37.65 \\
\hline Nuclear electricity & 0.052 & 0.005 & 0.006 & 0.063 & - \\
\hline Biomass electricity & 0.01 & 0.002 & 0.064 & 0.076 & - \\
\hline Hydropower and Others & 0 & 0 & 0 & 0 & - \\
\hline
\end{tabular}

\subsection{Life Cycle GHG Emissions Footprint of Different Vehicle Fuels}

The life cycle GHG emissions per MJ of vehicle fuel produced and used for the various production/consumption stages are shown in Figure 2. The results indicate that, apart for biomasspowered electricity, GHG emissions associated with transportation (of both raw materials and fuel products) contributed very little to the total life cycle emissions (from $0.22 \%$ to $3.15 \%$ ).

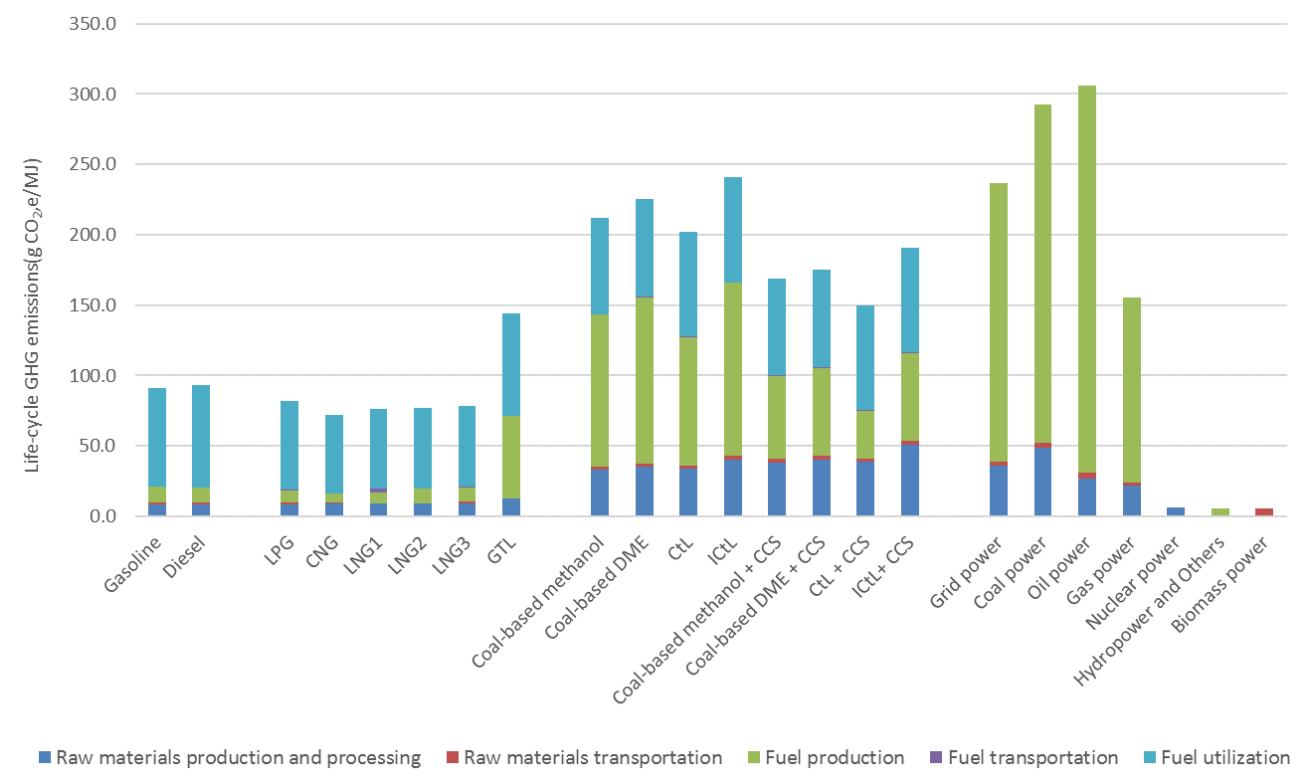

Figure 2. Life cycle GHG emissions for various vehicle fuels by stage. 


\subsubsection{Oil-based Fuel Pathways}

The life cycle GHG emissions for gasoline, diesel and LPG were 91.3, 93.3 and $82.2 \mathrm{~g} \mathrm{CO}_{2, \mathrm{e}} / \mathrm{MJ}$, respectively. For oil-based fuel pathways, GHG emissions in the (upstream) WTP stages accounted for a modest fraction of the total emissions: $23.41 \%, 22.11 \%$ and $23.25 \%$ for gasoline, diesel and LPG, respectively. Meanwhile, for the same fuels, GHG emissions from the fuel-use stage dominated the WTW totals at $76.59 \%, 77.89 \%$ and $76.75 \%$, respectively. During fuel use, GHG emissions from different fuel pathways are defined by the physical properties of the fuel, including their carbon content (CC) and the fuel oxidation rate (FOR).

\subsubsection{NG-Based Fuel Pathways}

At $72.3 \mathrm{~g} \mathrm{CO}_{2, \mathrm{e}} / \mathrm{MJ}$, life cycle GHG emissions for CNG were a little lower than those of conventional oil-based fuels, with $21.95 \%$ of the total attributed to upstream processes. The total GHG emissions for GTL were $143.9 \mathrm{~g} \mathrm{CO}_{2, \mathrm{e}} / \mathrm{MJ}$ with a similar proportion attributed to upstream processes $(49.53 \%)$ and fuel use phase $(50.47 \%)$. Regarding the LNG pathways, all GHG emissions associated with LNG 2 and LNG 3 were released within domestic boundaries. The emissions for LNG 2 and LNG 3 were 77.2 and $78.1 \mathrm{~g} \mathrm{CO}_{2, \mathrm{e}} / \mathrm{MJ}$, respectively, of which $25.99 \%$ and $26.90 \%$, respectively, were attributed to upstream processes. For LNG 1, the upstream GHG emissions, which were assumed to be emitted outside of national boundaries, were $19.50 \mathrm{~g} \mathrm{CO}_{2, \mathrm{e}} / \mathrm{MJ}, 25.69 \%$ of the total $\left(76.1 \mathrm{~g} \mathrm{CO}_{2, \mathrm{e}} / \mathrm{MJ}\right)$. These included NG exploitation and processing, NG liquefaction, and LNG transport to China, which accounted for $12.89 \%, 10.30 \%$, and $2.50 \%$ of the total, respectively. The GHG emissions associated with LNG transmission and distribution, and LNG use, which were assumed to occur in China, represented $56.42 \mathrm{~g} \mathrm{CO}_{2, \mathrm{e}} / \mathrm{MJ}$, or $74.31 \%$ of the total life cycle emissions.

\subsubsection{Coal-Based Fuel Pathways}

The life cycle GHG emissions for the methanol, DME, direct CtL and ICtL pathways were 212.1, 225.3, 202.1 and $240.6 \mathrm{~g} \mathrm{CO}_{2, \mathrm{e}} / \mathrm{MJ}$, respectively, which were 2.2-2.6 times greater than those associated with conventional gasoline. The main reasons for such high values were the low energy conversion rates of coal-based fuel plants and the associated consumption of primary fossil energy, especially of coal with its very high carbon content. The GHG emissions from the upstream stages outweighed those from fuel use, ranging from $63.24 \%$ to $69.22 \%$ of the total. Introducing CCS decreased the life cycle GHG emissions of the methanol, DME, direct CtL and ICtL pathways by $20.45 \%, 22.29 \%, 26.04 \%$ and $20.67 \%$, respectively. Simultaneously, the contribution from upstream operations fell to $59.41 \%$, $60.39 \%, 50.30 \%$ and $61.07 \%$ of the total for the respective pathways.

\subsubsection{Electricity (for EV) Pathways}

For the EV pathways, almost all of the GHG emissions were generated in the upstream, fuel-production stage. The total GHG emissions associated with coal-derived electricity was 292.3 $\mathrm{g} \mathrm{CO}_{2, \mathrm{e}} / \mathrm{MJ}$, in which the production, transportation and combustion of coal accounted for $16.72 \%, 1.10 \%$ and $82.17 \%$, respectively. Similarly, GHG emissions associated with the production and transportation of oil in the oil-powered electricity pathway accounted for $8.74 \%$ and $1.44 \%$ of the total life cycle emissions, respectively. Adding the GHG emissions from its combustion in a power plant, the total GHG emissions for oil-derived electricity were $305.7 \mathrm{~g} \mathrm{CO}_{2, \mathrm{e}} / \mathrm{MJ}$. The corresponding life cycle GHG emissions for gas-derived electricity were $155.5 \mathrm{~g} \mathrm{CO}_{2, \mathrm{e}} / \mathrm{MJ}$, of which raw material production and transportation were responsible for $13.94 \%$ and $1.45 \%$, respectively. Electricity pathways with non-fossil energy as the main raw material (such as nuclear, biomass and hydropower) had very small life cycle GHG emissions. Here, emissions tended to be concentrated in a specific sub-stage. For example, nearly all of the GHG emissions from of biomass-derived electricity was generated by transporting the raw material. The GHG emissions associated with the average grid electricity chain 
were $168 \mathrm{~g} \mathrm{CO}_{2, \mathrm{e}} / \mathrm{MJ}$, with raw material production, raw material transportation and generation in the electricity plant accounting for $15.18 \%, 1.13 \%$ and $83.69 \%$, respectively.

\subsection{Comparison between NG-Based and Electricity Pathways}

Table 10 shows a comparison of the varied results for NG-based and electricity pathways for studies conducted in China and several other countries. The current study updates previous work on China by considering the most up-to-date production technology that is in use in China today. Thus, fuel-conversion efficiencies are for the most part higher (Table A2), leading to a lower overall level of energy consumption and GHG emissions for the processes.

Nonetheless, the life cycle consumption of primary fossil energy and GHG emissions for the NG-based fuels and electricity pathways in China remained higher than those in other countries and regions. For electricity pathways, the difference is mainly due to the low proportion of low-carbon sources (29.1\%) and the large proportion of coal electricity (67.9\%) in China's electricity mix [49], the latter being significantly higher than in the other countries in the comparison (0-34.3\%) [7]. For NG-based fuel pathways, the differences can be attributed to: (1) China's coal-dominated energy mix; (2) China's lower efficiencies in the feedstock and fuel production stages (for example, for the CNG pathway, NG extraction, processing and CNG compression efficiencies in China were $96 \%, 94 \%$ and $96.9 \%$, respectively [23,34], while the respective values for the US were $98 \%, 98 \%$ and $97.9 \%$ [7]); and (3) China's higher energy intensities for various transport modes [32,34].

Table 10. Energy consumption and GHG emission intensity results for NG-based and electricity pathways from different studies.

\begin{tabular}{ccccc}
\hline Pathway & Region & Energy Intensity (MJ/MJ) & GHG Intensity $\left(\mathbf{g ~ C O}_{2, \mathrm{e}} \mathbf{\text { MJ }}\right)$ & Data Source \\
\hline Electricity & China & 2.25 & 203 & This study \\
Electricity & China & 2.70 & 230 & {$[16]$} \\
Electricity & China & 2.33 & 230 & {$[7]$} \\
Electricity & US & 1.92 & 162 & {$[7]$} \\
Electricity & Europe & 1.52 & 116 & {$[14]$} \\
\hline CNG & China & 1.20 & 72 & This study \\
CNG & China & 1.46 & - & {$[32]$} \\
CNG & China & 1.23 & 78 & {$[31]$} \\
CNG & US & 1.16 & 77 & {$[7]$} \\
CNG & Europe & 1.19 & 71 & {$[14]$} \\
\hline LNG & China & $1.28 /$ LNG 1, 1.24/LNG 2, 1.26/LNG 3 & $75.9 /$ LNG 1, 77.2/LNG 2, 78.1/LNG 3 & This study \\
LNG & US & 1.21 & 76.4 & {$[7]$} \\
\hline
\end{tabular}

\subsection{Comparison for WTW Results of Vehicle Fuels}

As shown in Figure 3, the life cycle primary fossil energy consumption for the various vehicle fuels investigated was broadly ordered (from highest to lowest) as follows: coal-based fuels, GTL, conventional oil-based fuels, LNG, CNG, CCS-fitted electricity generation, generation I biofuels, grid-powered electricity, and generation II biofuels.

As shown in Figure 4, the order for life cycle GHG emissions was as follows (again, from highest to lowest): coal-based fuels, coal-based fuels with CCS, waste oil-derived biodiesel, GTL, conventional oil-based fuels, generation I biofuels, gaseous and liquefied NG fuels, grid-powered electricity, CCS-fitted power generation and generation II biofuels.

Here we refer to the WTW analyses results of biofuel vehicle pathways and coal electricity with CCS [35] in the previous reports [33,41] by CAERC using TLCAM to gain a more comprehensive understanding of energy consumption and GHG emissions for the different vehicle fuel pathways calculated in this study.

Fuels derived from a coal-powered process that was not equipped with CCS showed fossil energy inputs and GHG emissions that were $47-132 \%$ and $88-189 \%$ higher than those for conventional gasoline and diesel pathways, respectively. This was attributed to low conversion efficiencies in coal-powered 
fuel plants and coal's high carbon content. Coal-powered methanol and DME plants in China are decentralized with the level of technology employed varying greatly, suggesting that the average value used here may mask a wide distribution of results. The application of CCS technology further increased the life cycle fossil energy inputs of coal-based fuel pathways. This resulted in life cycle primary energy consumption being $68-191 \%$ higher than in the conventional diesel and gasoline pathways, with the corresponding GHG emissions being 39-129\% higher. Uncertainties surrounding CCS's energy consumption and rate of carbon capture could further extend the range of real-world results for pathways that apply CCS.

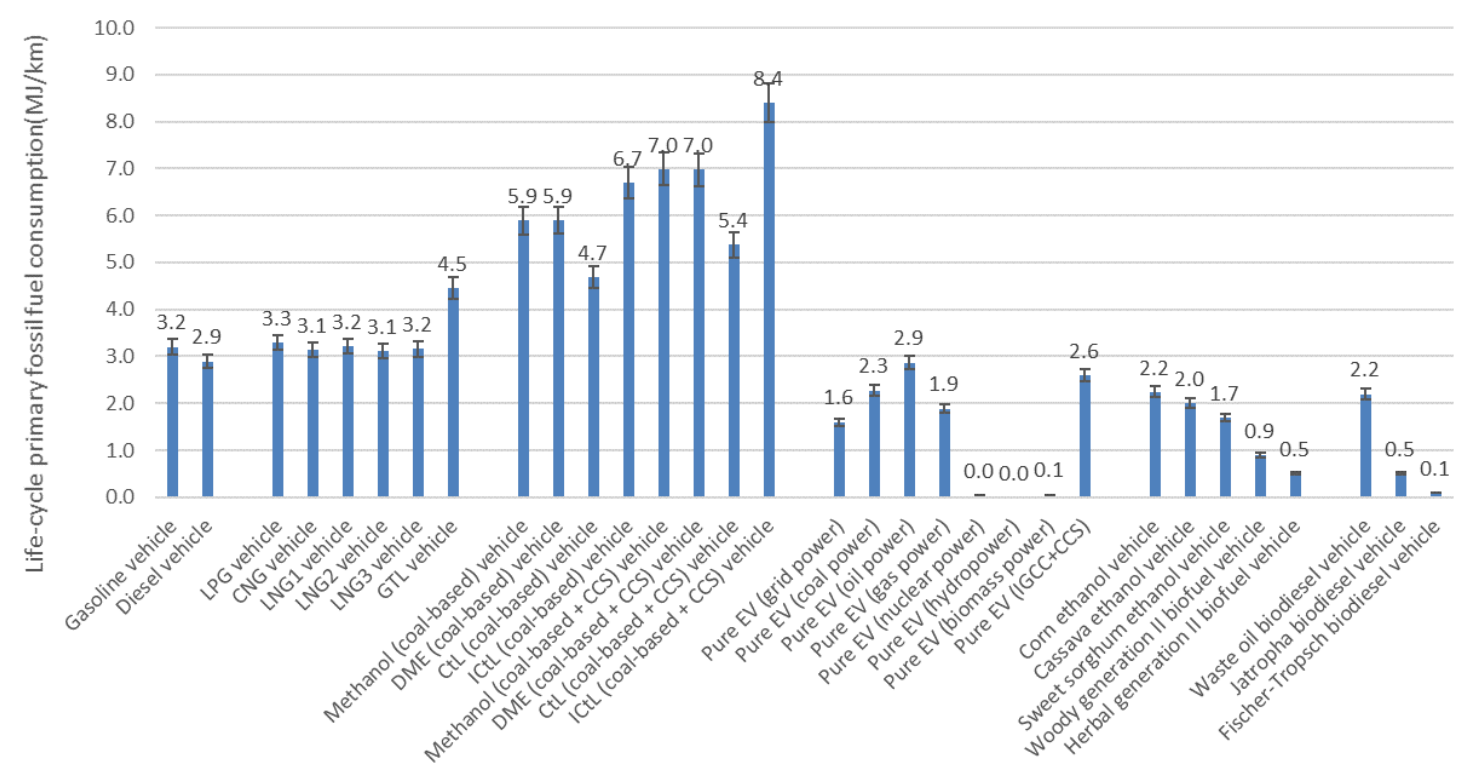

Figure 3. Life cycle primary fossil fuel consumption for various vehicle fuels (vehicle cycle excluded).

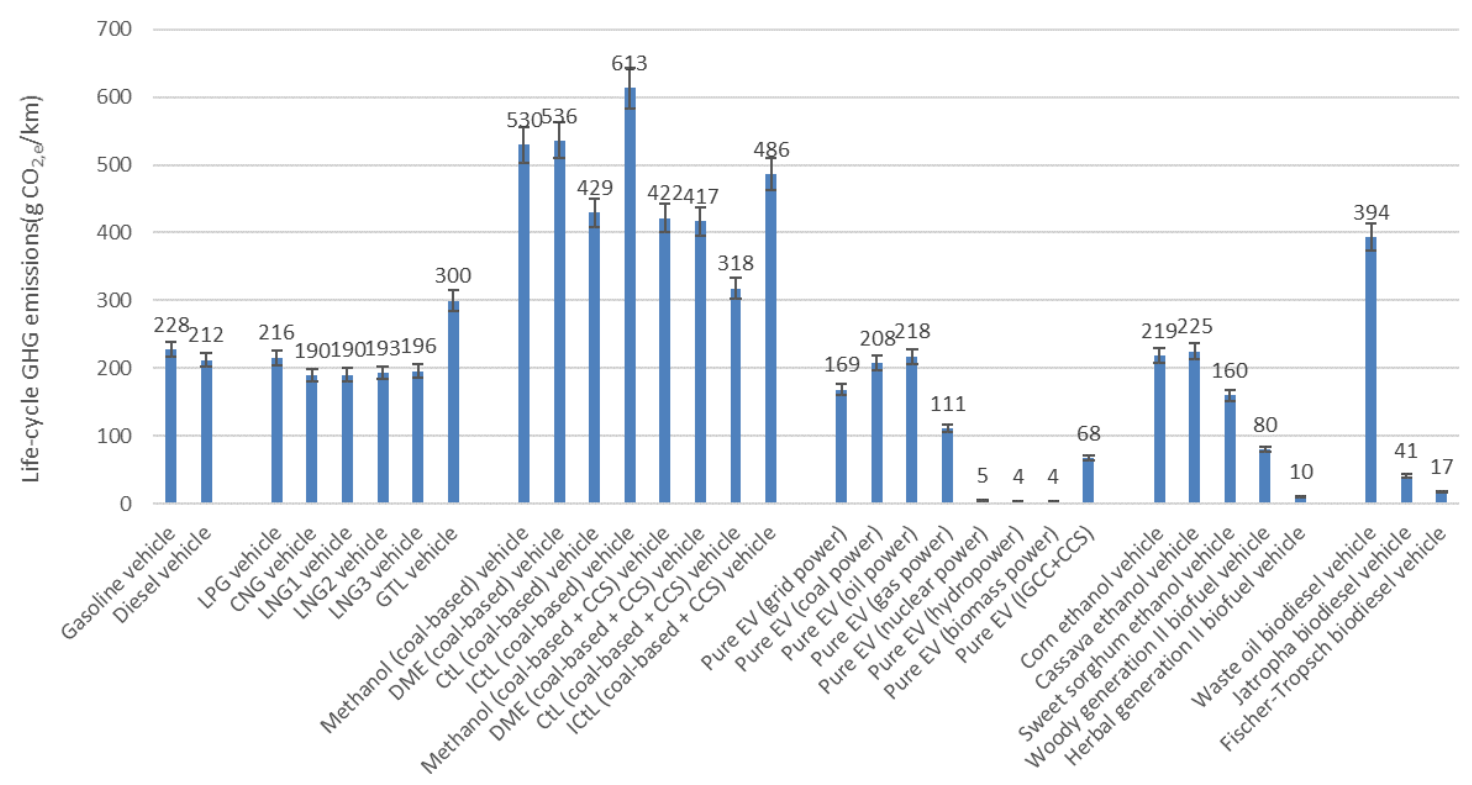

Figure 4. Life cycle GHG emissions for various vehicle fuels (vehicle cycle excluded).

While the life-cycle fossil energy consumption of the CNG and LNG pathways were almost the same as those for the conventional gasoline pathway, because the carbon content of NG is lower than that of oil, the CNG and LNG pathways reported lifecycle GHG emissions that were 14-17\% lower than those for the conventional gasoline pathway, and $8-10 \%$ lower than those for the conventional diesel 
pathway. For LNG 1, domestic GHG emissions were 35\% and 31\% lower than those for conventional gasoline and diesel vehicles, respectively. Variance in results for CNG and LNG pathways can mainly be attributed to differences in the transport distance. For GTL pathways, life cycle fossil energy consumption was $54 \%$ greater than that for conventional diesel vehicles because the production efficiency of a GTL plant is relatively low. However, NG's lower carbon content meant that life cycle GHG emissions were only $41 \%$ higher than those from conventional diesel vehicles. Variability in current and future conversion efficiencies for GTL plants could create a wide distribution around this average result.

Life cycle fossil energy consumption of EVs using grid electricity was $50 \%$ of that consumed by a comparable gasoline vehicle, and $55 \%$ of the amount consumed by a comparable diesel vehicle. This decrease was mainly attributed to the much higher energy efficiency of EVs compared with that of ICEs. Because coal is the major source of electricity generation in China, the EV-pathway GHG emissions were only $26 \%$ and $21 \%$ less than those for conventional gasoline and diesel vehicle pathways, respectively. Using electricity derived solely from coal or oil resulted in very similar results to those obtained for the conventional diesel vehicle pathway. However, using nuclear, biomass or hydro-electricity resulted in WTW fossil energy inputs and GHG emissions that were only $1-2 \%$ of those for conventional gasoline and diesel vehicle pathways.

Biofuels offer obvious potential to decrease fossil energy consumption and GHG emissions. Vehicles powered by Generation I biofuels were found to effect 1-30\% decreases in GHG emissions and $30-47 \%$ decreases in the consumption of fossil energy inputs compared with results for conventional gasoline vehicles. The life cycle fossil energy consumption for the pathway based on waste oil biodiesel was $69 \%$ of that consumed for a comparable gasoline vehicle; however, life cycle GHG emissions were $73 \%$ higher than comparable diesel vehicle. For generation II biofuel vehicles, life cycle fossil energy consumption and GHG emissions were $72-97 \%$ and $65-93 \%$ lower than the comparable gasoline/diesel vehicle, respectively.

\subsection{Sensitivity Analysis of Carbon Footprint of LNG Pathways and Coal-Based Fuel Pathways}

From the analysis of the three LNG pathways considered, the efficiency of NG liquefaction and the mix of fuel during liquefication process impacted the GHG emissions intensity the most. Emissions intensity was only weakly sensitive to changes in the distance over which NG was transported and over which LNG was transmitted and distributed. Specifically, for the LNG 1 pathway, if we were to assume that the foreign liquefaction plant was powered by electricity and had an overall energy efficiency of $95.2 \%$, re-calculation of the life cycle value yields a GHG emissions intensity of $79.1 \mathrm{~g} \mathrm{CO}_{2, \mathrm{e}} / \mathrm{MJ}$, a $4.1 \%$ increase over a situation where the plant is powered by NG. For the LNG 2 pathway, if we assume that the liquefaction plant is powered by NG and has an overall energy efficiency of $90.2 \%$, the total GHG emissions intensity would be $74.7 \mathrm{~g} \mathrm{CO}_{2, \mathrm{e}} / \mathrm{MJ}$, a $3.2 \%$ decrease compared with the plant being powered by electricity. For the LNG 3 pathway, if we assume that the liquefaction plant is powered by NG and has an overall energy efficiency of $90.2 \%$, the total GHG emissions intensity would be $75.7 \mathrm{~g} \mathrm{CO}_{2, \mathrm{e}} / \mathrm{MJ}, 3.15 \%$ lower than when the plant is powered by electricity. Meanwhile, a 50\% decrease in NG transportation and LNG transmission and distribution distances results in GHG emissions intensities for the three pathways changing from 75.9, 77.2 and 78.1 $\mathrm{g} \mathrm{CO}_{2, \mathrm{e}} / \mathrm{MJ}$ to $75.4,76.9$ and 77.4 $\mathrm{g} \mathrm{CO}_{2, \mathrm{e}} / \mathrm{MJ}$, respectively, representing respective decreases of $0.65 \%, 0.31 \%$ and $0.93 \%$.

Compared to LNG pathways, coal-based fuel pathways were more sensitive to energy efficiency and the process fuel mix. For Direct $\mathrm{CtL}$, ICtL, Methanol and DME pathways, if we were to assume that the overall energy efficiencies were $\%$ lower than before, the GHG emissions intensities would be $212.8,253.2,225.3$ and $239.1 \mathrm{CO}_{2, \mathrm{e}} / \mathrm{MJ}$, respectively, representing respective increase of $5.3 \%, 5.3 \%$, $6.3 \%$ and $6.1 \%$. For the four coal-based fuel pathways, if we assume that $50 \%$ of the process fuel were from extra electricity, the total GHG emissions intensities would be increased to 325.6, 387.8, 255.3 and $274.6 \mathrm{CO}_{2, \mathrm{e}} / \mathrm{MJ}$, respectively, representing respective increase of $61.1 \%, 61.1 \%, 20.4 \%$ and $21.9 \%$ over the original situation. Meanwhile, a $50 \%$ decrease in coal transportation and coal-based fuel 
transmission and distribution distances results in GHG emissions intensities for the four pathways decreasing from 202.1, 240.6, 212.1 and $225.3 \mathrm{CO}_{2, \mathrm{e}} / \mathrm{MJ}$ to $200.8,239.0,210.8$ and $223.9 \mathrm{CO}_{2, \mathrm{e}} / \mathrm{MJ}$, respectively, representing respective decrease of $0.69 \%, 0.67 \%, 0.65 \%$ and $0.64 \%$.

\subsection{Impact of Expanding the System Boundary to Vehicle Cycle}

Energy consumption and GHG emissions attributed to materials production and transportation, vehicle/battery manufacture, vehicle decommissioning and recycling typically are important in LCA but this kind of works are relied on credible data heavily. Referring to Qiao et al. [50], shown in Table 11, if vehicle lifetime was assumed to be $200,000 \mathrm{~km}$, we could estimate the life cycle energy consumption of a standard mid-size BEV with $\mathrm{Li}(\mathrm{NiCoMn}) \mathrm{O}_{2}(\mathrm{NMC}) / \mathrm{LiFePO}_{4}$ (LFP) and an ICEV are $0.46 / 0.47$ and $0.32 \mathrm{MJ} / \mathrm{km}$, respectively, accounting for $44.3 \% / 44.8 \%$ and $21.9 \%$ of the whole fuel cycle. The life cycle GHG emissions are 75.0/75.9 and $49.9 \mathrm{~g} \mathrm{CO}_{2, \mathrm{e}} / \mathrm{km}$, respectively, representing $28.9 \% / 29.5 \%$ and $9.9 \%$ of the whole fuel cycle. The life cycle GHG emissions from the production of a BEV with NMC/LFP and a ICEV are 14.6/14.7 and $9.2 \mathrm{t} \mathrm{CO}_{2, \mathrm{e}}$. in earlier study [51]. Especially for the production of traction battery, the life cycle GHG emissions are significant, ranging from 2.7 to $3.1 \mathrm{tCO}_{2, \mathrm{e}}$ in China [50-52]. The total energy consumption and GHG emissions resulted from vehicle cycle can be reduced largely when considering most of the material in the vehicles can be recycled though the impact was still obvious and could not be negligible [53].

Table 11. Life cycle energy consumption and GHG emissions from vehicle cycle [50].

\begin{tabular}{lcccc}
\hline & Unit & ICEV & BEV-NMC & BEV-LFP \\
\hline Life cycle energy consumption & MJ/per vehicle & 63.515 & 92,392 & 94,341 \\
Life cycle GHG emissions & $\mathrm{kg} \mathrm{CO}_{2, \mathrm{e}} /$ per vehicle & 9985 & 15,005 & 15,174 \\
\hline
\end{tabular}

Both the life cycle energy consumption and GHG emissions of a BEV were higher than those of an ICEV [50-53]. Compared with an equivalent ICEV, a BEV has a different motor, a traction battery and several other new systems that mean the life cycle results of vehicle cycle would be different due to the production of these new and additional components. For various ICEV pathways, the components of standard middle-size passenger vehicles are basically the same, with tiny difference among them such as spark plug. Thus, we assumed that the total GHG emissions from ICEV production were the same for different vehicle/fuel pathway in this paper.

In other words, the inclusion of the vehicle cycle can improve the life cycle analysis method and update the existing results significantly. As shown in Figure 5, the total life cycle GHG emissions of a BEV charged by grid power is only $12 \%$ less than that of a gasoline vehicle. Particularly, coal -and oil-powered BEVs caused more GHG emissions than gasoline vehicles, due to that BEVs tended to have larger battery and new components which lead to higher emissions.

Three major factors were analyzed for sensitivity by Qiao et al. [50], including curb weight, GHG emissions factor of electricity production and traction battery. The results indicated that when the curb weight is changed by $10 \%$, the GHG emissions from the production of a BEV with NMC/LFP and a ICEV would be influenced by $7.3 \%, 6.7 \%$ and $6.6 \%$, respectively. Amounts of electricity is consumed during vehicle production, the result showed that the value respective were $3.7 \%, 3.8 \%$ and $3.9 \%$, respectively, when the GHG emissions factor of grid mix changes by $10 \%$. 


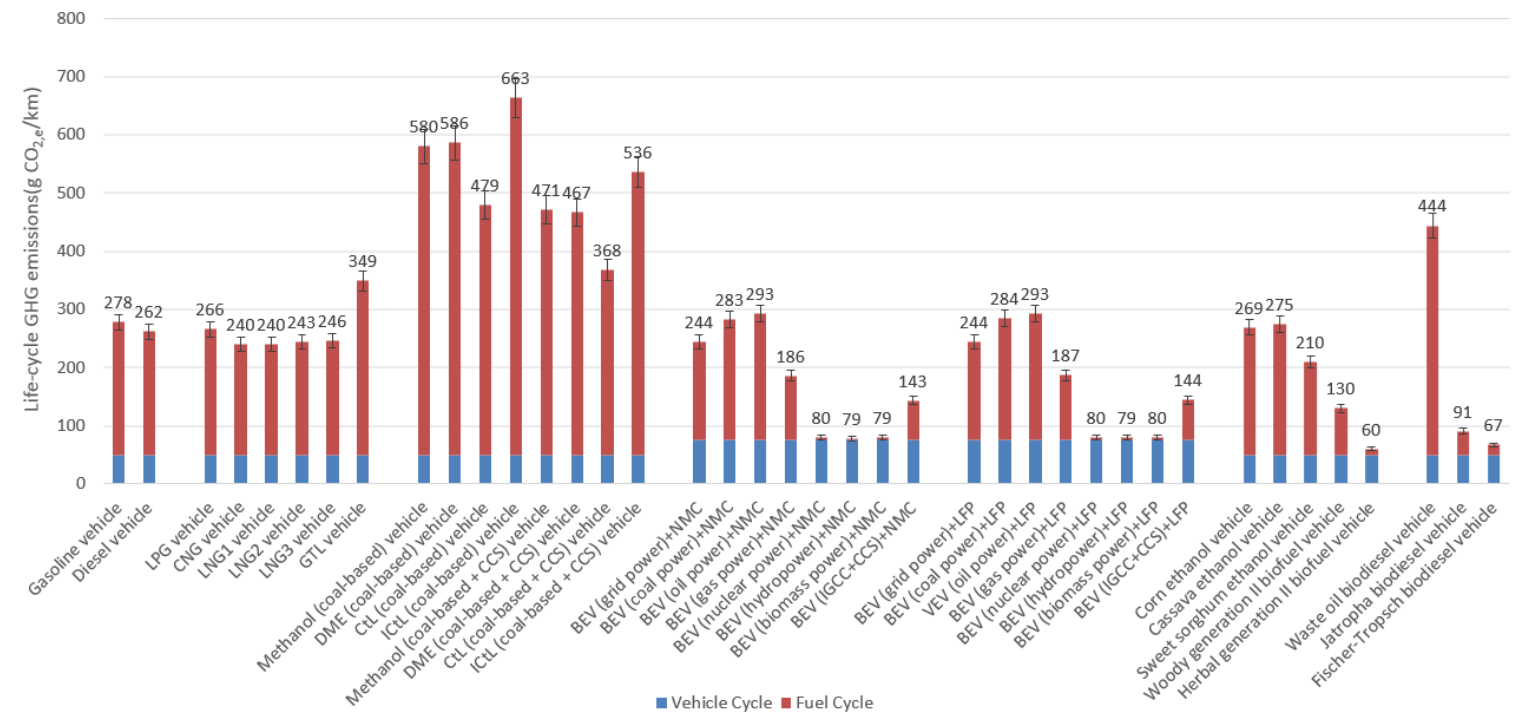

Figure 5. Life cycle GHG emissions for various vehicle fuels (vehicle cycle included).

\subsection{Limitations and Further Work of Our Work}

It should be noted that this analysis was not strictly compliant with the guidelines of ISO 14040 and 14044 and could not do compilation and evaluation of potential environmental impacts of a product system throughout its life cycle. However, as a very important method in energy system analysis, life cycle analysis method has been widely used globally. A great number of researchers have made efforts to conduct the life cycle analysis of different products and technical pathways. With the increasing demand of vehicle energy and global warming, life cycle energy consumption and GHG emissions have become critical and necessary information influencing the implementation of relevant energy policies, thus most of the studies mainly focus on the two indicators, but did not analyze all relevant environmental impacts as Zah et al. [54] done. To be honest, our analysis did also not fulfil the requirement of ISO standard, though we have made great effort to investigate the energy consumption and GHG emission of vehicle fuel in China.

In addition, the infrastructure and facilities manufacturing such as power plant and oil drilling, and maybe also the abrasive emissions were all important parts of LCA. They were excluded in the system boundary of this study and the significance of them deserve investigating with more credible data.

Furthermore, this analysis only took three types of primary fossil energy input into consideration, this limitation might underestimate the impact of non-fossil fuel energy such as nuclear power and renewable energy, thus the indicator based on cumulative energy consumption would be much more meaningful and practical than our current study.

One more limitation of our analysis is the full evaluation on non-fossil fuel energy has not been taken though the energy consumption and GHG emissions performance is investigated. Some scholars are arguing that the development of non-fossil fuel energy has broader and environmental impacts and cannot be ignored. For example, radioactive emissions are important for the full environmental impacts of nuclear power development.

Accordingly, plenty of works will be further taken to improve our work in future in two key dimensions, to expand the system boundary and to cover full environment impacts analysis.

\section{Conclusions}

This work has shown that it is important to include China-specific characteristics in the LCA of alternative fuel vehicles in China. The following specific conclusions may be drawn: 
(1) China's current energy system is dominated by coal with a low overall energy efficiency. Together, these facts hinder the realization of potential decreases in fossil energy consumption and GHG emissions that alternative fuels may offer for vehicles, even if they are able to replace oil as the primary energy source.

(2) The potential for decreasing the consumption of fossil energy and GHG emissions for the EV pathways, will be more easily realized in the future. Compared with a conventional ICE vehicle driven by coal-derived liquid fuel, coal-powered EV pathways will offer obvious advantages in the future. EV pathways that are powered by a low-carbon electricity grid offer the most potential for future alternative vehicle fuels.

(3) NG-based fuel pathways showed similar levels of fossil energy consumption and GHG emissions to those for conventional gasoline and diesel vehicles. If only domestically emitted GHGs are considered, the emissions for vehicles in China powered by imported LNG are approximately a third less than for conventional gasoline and diesel vehicles.

(4) The GHG emissions intensity and energy intensity of conventional coal-based fuel pathways are approximately 1.5-2.6 and 1.1-2.6 times greater, respectively, than those of the conventional gasoline pathway. Applying CCS increases fossil energy consumption to achieve the desired decrease in GHG emissions intensity; however, this remains much higher than that of the conventional gasoline pathway.

(5) GHG emissions reduction effect of EV pathways will be lower when the vehicle cycle is included, because the GHG emissions from the production of an EV are higher great than ICEV. EVs charged by coal-power even show higher GHG emissions than those of gasoline ICEVs when both the vehicle-cycle and fuel cycle are included.

To promote alternative fuel/vehicle development and guarantee on-road vehicle energy demand, policymakers should establish near-, medium-, and long-term strategies and introduce practical policies to resolve the following key issues:

(i) To satisfy the increasing on-road vehicle energy demand, in the near-to-medium term, the main aim should be to promote the development of NG-based and coal-based fuels to partly substitute oil-derived fuels. In the longer term, the goal is to promote the development of EVs and R \& D into CCS technology to affect a significant replacement of oil consumption and a substantial decrease in GHG emissions.

(ii) Combined technology-push and market-pull policies not only directly support the development of low-carbon fuel technology but also promote the large-scale industrial development and market penetration of low-carbon fuels. Corresponding recommendations include:

- Encourage conventional vehicles to use fossil energy-saving technologies, such as hybrid EVs.

- Promote the development of renewable energy, and accelerate R \& D to commercialize CCS and other low-carbon electricity technologies.

- Accelerate the construction of transmission, distribution, and filling infrastructure for alternative liquid fuels.

- Support the demonstration of commercial operation of EVs to promote market expansion and the construction of charging infrastructure.

- Promote low-carbon liquid alternative fuels through the active development of the coal chemical industry, application of CCS technology as well as the development of second generation biofuels.

- Optimize the production process of vehicle (especially battery materials) to lower the GHG emissions during the manufacturing of vehicle.

- Accelerate the vehicle recycling industry, and promote the development of effective vehicle recycling techniques. 
Acknowledgments: This project was co-sponsored by the National Natural Science Foundation of China (71774095, 71690244 and 71673165) and International Science \& Technology Cooperation Program of China (2016YFE0102200). The authors thank the reviewers for their valuable comments.

Author Contributions: Xunmin Ou conceived and designed the research framework. Tianduo Peng, Sheng Zhou, Zhiyi Yuan and Xunmin Ou analyzed the data and wrote the paper.

Conflicts of Interest: The authors declare no conflict of interest.

\section{Nomenclature}

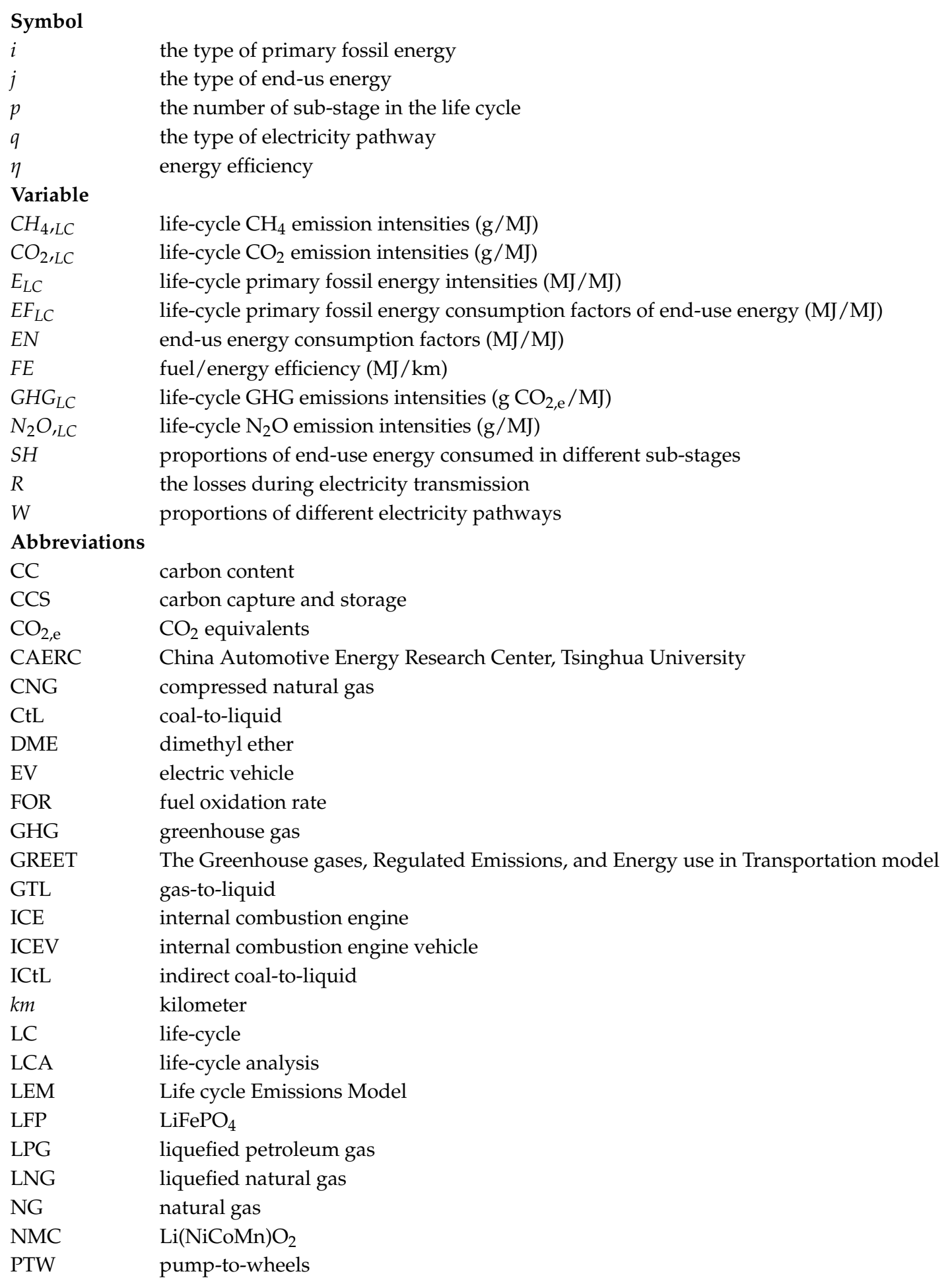


TLCAM Tsinghua life-cycle analysis model

WTP well-to-pump

WTW well-to-well

\section{Appendix A. Calculation of Life Cycle Factors for a Given End-Use Energy}

\section{A.1. Basic Definitions and Assumptions}

The fossil energy intensity $\left(E F_{L C}, \mathrm{MJ} / \mathrm{MJ}\right)$ and $\mathrm{GHG}$ emissions intensity $\left(G H G_{L C}, \mathrm{~g} \mathrm{CO}_{2, \mathrm{e}} / \mathrm{MJ}\right)$ for a given secondary energy (SE) were defined as the sum of all the primary fossil energy consumption (PFEC) and GHG emissions, respectively, across the entire fuel life cycle required to produce and use $1 \mathrm{MJ}$ of the end-use energy.

As Table A1 shows, three fossil primary energies (PEs) were considered-coal, NG, and petroleum ( $i$ represents the type of PE)—alongside nine SEs (represented by $j, x$ or $z$ ). For each SE, the LCA included $m$ stages. For electricity generation (as denoted by $n$ ), four energy sources were considered: coal, NG, oil and "other".

Table A1. Energy types and production stages modeled.

\begin{tabular}{ccccc}
\hline No. & $\boldsymbol{i}$ (PE) & $j, x$ or $z$ (SE) & $m$ (Stage Name) & $n$ (Electricity Pathway) \\
\hline 1 & Coal & Crude coal $^{\text {a }}$ & Feedstock production & Coal-based \\
2 & NG & Crude NG $^{\mathrm{b}}$ & Feedstock transportation & NG- based \\
3 & Petroleum & Crude oil $^{\mathrm{b}}$ & Fuel production & Oil-based \\
4 & - & Coal $^{\mathrm{c}}$ & Fuel transportation & Others \\
5 & - & NG $^{\mathrm{c}}$ & - & - \\
6 & & Diesel & & \\
7 & & Gasoline & & \\
8 & & Residual oil & & \\
9 & & Electricity & & \\
\hline
\end{tabular}

Note: ${ }^{\mathrm{a}}$ only recovered; ${ }^{\mathrm{b}}$ recovered and processed; ${ }^{\mathrm{c}}$ recovered, processed and transported.

\section{A.2. Calculation of Fossil Energy Intensity}

$E F_{L C, j}$ (the life cycle PFEC intensity of SE $j$ ) was calculated as the sum of all values of $E F_{L C, j, i}$ (the life cycle PE $i$ intensity of SE $j$ ):

$$
E F_{L C, j}=\sum_{i=1}^{3} E F_{L C, j, i}(j=1,2, \ldots, 9)
$$

$E F_{L C, j, i}$ was calculated using $E I_{m, j}$ (the total PE input during sub-stage $m$ to produce $1 \mathrm{MJ}$ of SE $j$ ), $S H_{m, j, z}$ (the share of SE $z$ in the sub-stage $m^{\prime}$ 's total energy use per MJ of SE $j$ produced) and $E F_{L C, z, i}$ (the life cycle PE $i$ intensity of SE $z$ ):

$$
\begin{gathered}
E F_{L C, j, i}=\sum_{m=1}^{4}\left(E I_{m, j} \sum_{z=1}^{9}\left(S H_{m, j, z} E F_{L C, z, i}\right)\right)+\delta_{i, j} \\
\delta_{i, j}=\left\{\begin{array}{cc}
\text { when } \\
0 & \text { otherwise }
\end{array}(i, j) \in\{(1,1),(1,4),(2,2),(2,5),(3,3),(3,6),(3,7),(3,8) \quad\}\right.
\end{gathered}
$$

Thus, $E F_{L C, j}$ could be calculated as:

$$
\left\{\begin{array}{l}
E F_{L C, j}=\sum_{i=1}^{3} \sum_{m=1}^{4}\left(E I_{m, j} \sum_{z=1}^{9}\left(S H_{m, j, z} E F_{L C, z, i}\right)\right)+\gamma_{j} \\
\gamma_{j}= \begin{cases}0 & \text { for } j=9 \\
1 & \text { otherwise }\end{cases}
\end{array}\right.
$$

For a non-electricity $\mathrm{SE}(j=1,2, \ldots, 8), E I$ was derived from sub-stage $m^{\prime}$ s energy-transformation efficiency factor per MJ of SE $j$ obtained $\left(\eta_{m, j}\right)$ and the conversion factor from feedstock to fuel during the fuel production sub-stage for $\operatorname{SE} j\left(\xi_{j} ; \mathrm{MJ} / \mathrm{MJ}\right)$ :

$$
\begin{aligned}
& E I_{1, j}=\left(1 / \eta_{1, j}-1\right) / \xi_{j}(j=1,2, \ldots, 8) \\
& E I_{2, j}=\left(1 / \eta_{2, j}-1\right) / \xi_{j}(j=1,2, \ldots, 8)
\end{aligned}
$$




$$
\begin{aligned}
& E I_{3, j}=1 / \eta_{3, j}-1(j=1,2, \ldots, 8) \\
& E I_{4, j}=1 / \eta_{4, j}-1(j=1,2, \ldots, 8)
\end{aligned}
$$

For electricity $(j=9)$, the life cycle calculations were computed directly from sub-stage 3 using the nationally averaged supply mix to the grid:

$$
E I_{m, 9}=\left\{\begin{array}{cl}
\sum_{n=1}^{4}\left(R A_{n} / \eta_{3,9, n} / \eta_{4,9, n}\right) & \text { for } m=3 \\
0 & \text { otherwise }
\end{array}\right.
$$

where $R A_{n}$ is the ratio of the $n$th electricity pathway to the total electricity generation; and $\eta_{3,9, n}$ and $\eta_{4,9, n}$ are the energy transformation efficiency factors for the electricity generation and the electricity transmission and distribution sub-stages for the $n$th electricity pathway, respectively.

Based on Equations (A1)-(A8), $\eta_{m, j}, \xi_{j}$ and $S H_{m, j, z}$ were required for to calculate $E F_{L C, j, i}(j=1,2, \ldots, 8)$ and $R A_{n}, \eta_{3,9, n}$ and $\eta_{4,9, n}$ were necessary to calculate $E F_{L C, 9, i}$. Because coal, NG, and crude oil occur as both PEs and SEs, Equations (A2)-(A7) were solved using an iterative computational method.

\section{A.3. Calculation of GHG Emissions Intensities}

\section{A.3.1. General Description}

The life cycle GHG emissions intensity of SE $j\left(G H G_{L C, j}\right)$ consists of the three key types of GHG emissions $\left(\mathrm{CO}_{2}, \mathrm{CH}_{4}\right.$ and $\left.\mathrm{N}_{2} \mathrm{O}\right)$. These types of $\mathrm{GHG}$ were converted into $\mathrm{CO}_{2}$ equivalents $\left(\mathrm{CO}_{2, e}\right)$ according to their global warming potential $[39,40]$ :

$$
G H G_{L C, j}=C_{2, L C, j}+25 \mathrm{CH}_{4, L C, j}+298 \mathrm{~N}_{2} \mathrm{O}_{L C, j}
$$

where $\mathrm{CO}_{2, L C, j}, \mathrm{CH}_{4, L C, j}$ and $\mathrm{N}_{2} \mathrm{O}_{L C, j}$ are the life cycle $\mathrm{CO}_{2}, \mathrm{CH}_{4}$ and $\mathrm{N}_{2} \mathrm{O}$ emission intensities for SE $j$, respectively.

Similar to $E F_{L C, j, i}, G H G_{L C, j}$ was also calculated using an iterative method (which involved Equations (A12), (A15) and (A18)).

\section{A.3.2. $\mathrm{CO}_{2}$ Emissions}

$\mathrm{CO}_{2, \mathrm{LC}, j}$ consists of two parts: emissions from upstream processes $\left(\mathrm{CO}_{2, u p, j}, \mathrm{~g} / \mathrm{MJ}\right)$ and direct emissions from the fuel-combustion process $\left(\mathrm{CO}_{2, \text { direct }}, \mathrm{g} / \mathrm{MJ}\right)$ :

$$
\begin{gathered}
\mathrm{CO}_{2, L C, j}=\mathrm{CO}_{2, \text { up }, j}+\mathrm{CO}_{2, \text { direct }, j} \\
\mathrm{CO}_{2, \text { direct }, j}=\frac{44}{12} \mathrm{CC}_{j} \mathrm{FOR}_{j}
\end{gathered}
$$

where $C C_{j}$ is the carbon content of $\mathrm{SE} j(\mathrm{~g} / \mathrm{MJ}) ; F O R_{j}$ is the fuel oxidation rate of $\mathrm{SE} j$; and $\frac{44}{12}$ is the mass conversion factor between $\mathrm{C}$ and $\mathrm{CO}_{2}$.

Upstream $\mathrm{CO}_{2}$ emissions $\left(\mathrm{CO}_{2, u p, j}\right)$ result from the direct $\mathrm{CO}_{2}$ emissions during the production of SE $x$ $\left(\mathrm{CO}_{2, \text { direct }, x}, \mathrm{~g} / \mathrm{MJ}\right)$ :

$$
\mathrm{CO}_{2, u p, j}=\sum_{m=1}^{4} \sum_{x=1}^{9}\left(E I_{m, j} S H_{m, j, x}\left(\mathrm{CO}_{2, \text { direct }, x}+\mathrm{CO}_{2, u p, x}\right)\right)
$$

$\mathrm{CO}_{2, \text { direct }, x}$ was then calculated using the following carbon-balance equation:

$$
\mathrm{CO}_{2, \text { direct }, x}=\frac{44}{12} \mathrm{CC}_{x} \mathrm{FOR}_{x}
$$

where $C C_{x}$ is the carbon content of $\mathrm{SE} x(\mathrm{~g} / \mathrm{MJ}) ; F O R_{x}$ is the fuel oxidation rate of SE $x$; and $\frac{44}{12}$ is the mass conversion rate between $\mathrm{C}$ and $\mathrm{CO}_{2}$.

\section{A.3.3. $\mathrm{CH}_{4}$ Emissions}

Similarly, $\mathrm{CH}_{4, \mathrm{LC}, j}$ also consists of an upstream part $\left(\mathrm{CH}_{4, u p, j}\right)$ and a term that represents direct emissions from combustion $\left(\mathrm{CH}_{4, \text { direct }, j}\right)$ :

$$
\begin{gathered}
\mathrm{CH}_{4, L C, j}=\mathrm{CH}_{4, u p, j}+\mathrm{CH}_{4, \text { direct }, j} \\
C H_{4, u p, j}=\sum_{m=1}^{4} \sum_{x=1}^{9}\left(E I_{m, j} S H_{m, j, x}\left(\mathrm{CH}_{4, \text { direct }, m, x}+\mathrm{CH}_{4, u p, x}\right)\right)+\mathrm{CH}_{4, j, \text { noncomb }}
\end{gathered}
$$




$$
\mathrm{CH}_{4, j, \text { noncomb }}=\mathrm{CH}_{4, j, \text { resource }} / \xi_{j}
$$

where $\mathrm{CH}_{4, \text { direct,m,x }}$ is the direct $\mathrm{CH}_{4}$ emissions during the sub-stage $m$ (g/MJ) of the production of SE $x$; $\mathrm{CH}_{4, j, \text { noncomb }}$ corresponds to the indirect $\mathrm{CH}_{4}$ emissions from non-combustion sources, including spills and losses during NG extraction (g/MJ SE j); and $\mathrm{CH}_{4, \text { resource }}$ corresponds to indirect $\mathrm{CH}_{4}$ emissions during the resource extraction stage $(\mathrm{g} / \mathrm{MJ}$ resource obtained).

\section{A.3.4. $\mathrm{N}_{2} \mathrm{O}$ Emissions}

$\mathrm{N}_{2} \mathrm{O}_{L C, j}$ also consists of an upstream component $\left(\mathrm{N}_{2} \mathrm{O}_{u p, j}\right)$ and direct emissions released during combustion $\left(\mathrm{N}_{2} \mathrm{O}_{\text {direct }, j}\right)$ :

$$
\begin{gathered}
N_{2} O_{L C, j}=N_{2} O_{u p, j}+N_{2} O_{\text {direct }, j} \\
N_{2} O_{u p, j}=\sum_{m=1}^{4} \sum_{x=1}^{9}\left(E I_{m, j} S H_{m, j, x}\left(N_{2} O_{\text {direct }, m, x}+N_{2} O_{u p, x}\right)\right)
\end{gathered}
$$

where $\mathrm{N}_{2} \mathrm{O}_{\text {direct, } m, x}$ is the direct $\mathrm{N}_{2} \mathrm{O}$ emissions released for SE $x$ during stage $m$ (g/MJ).

\section{A.4. Basic Calculation Data}

This section presents the basic data used for the calculation of the life cycle fossil energy consumption factors $\left(\mathrm{EF}_{\mathrm{LC}}\right)$ and $\mathrm{GHG}$ emissions factors $\left(\mathrm{GHG}_{\mathrm{LC}}\right)$ for the nine end-use energies. Table A2 presents original, China-specific data for oil-, NG-, and coal-based fuels and electricity and includes energy conversion efficiencies, transport distances and the proportion of the different process fuels used in the various resource exploitation, transport, fuel processing and fuel production stages. The energy intensity and breakdown of fuels used by various transport modes are shown in Table A3. Direct and indirect GHG emissions released from the use of

\begin{tabular}{|c|c|c|}
\hline Item & Description & Data Source \\
\hline (1) Oil exploitation & & \multirow{3}{*}{$\begin{array}{c}{[2]} \\
{[7,34]}\end{array}$} \\
\hline Crude oil import proportion & \multirow{3}{*}{$\begin{array}{l}64.4 \%(2015) \\
93 \% \text { (Domestic), } 98 \% \text { (Imported) } \\
\text { Refined NG (43\%), crude oil ( } 28 \% \text { ), electricity }(14 \%) \text {, diesel }(9 \%) \text {, } \\
\text { raw coal }(4 \%) \text { residual oil }(1 \%) \text { and gasoline }(1 \%)\end{array}$} & \\
\hline Oil exploitation efficiency & & \\
\hline Fuel mix for oil exploitation & & [42] \\
\hline (2) Oil transportation mode & $\begin{array}{l}\text { Sea tanker: } 60 \%(11,000 \mathrm{~km}) \text {; rail: } 30 \%(942 \mathrm{~km}) \text {; pipeline: } \\
78 \%(440 \mathrm{~km}) \text {; waterway: } 10 \%(250 \mathrm{~km})\end{array}$ & {$[34,55]$} \\
\hline (3) Oil refining & \multirow{5}{*}{$\begin{array}{l}\text { Crude oil }(79 \%) \text {, raw coal }(6 \%) \text {, electricity }(6 \%) \text {, refined NG }(4 \%) \text {, } \\
\text { clean coal }(3 \%) \text {, residual oil }(2 \%) \\
89.1 \%\end{array}$} & \multirow[b]{2}{*}{ [42] } \\
\hline Process fuel mix for oil refinery & & \\
\hline Gasoline production efficiency & & \multirow{2}{*}[34]{} \\
\hline Diesel production efficiency & & \\
\hline Residual oil production efficiency & & [34] \\
\hline $\begin{array}{l}\text { (4) Gasoline, Diesel and Fuel oil } \\
\text { transportation mode }\end{array}$ & $\begin{array}{l}\text { Railway: } 50 \%(900 \mathrm{~km}) \text {; pipeline: } 15 \%(160 \mathrm{~km}) \text {; waterway: } \\
10 \% \text { (1200 km); road (short distance): } 10 \%(50 \mathrm{~km})\end{array}$ & {$[34,55]$} \\
\hline $\begin{array}{l}\text { (5) NG exploitation and processing } \\
\text { NG exploitation efficiency }\end{array}$ & \multirow{3}{*}{$\begin{array}{l}96 \% \\
\text { Refined NG }(43 \%) \text {, crude oil }(28 \%) \text {, electricity }(14 \%) \text {, diesel }(9 \%) \text {, } \\
\text { raw coal }(4 \%) \text { residual oil }(1 \%) \text { and gasoline }(1 \%)\end{array}$} & \multirow{2}{*}{$\begin{array}{l}{[34]} \\
{[42]}\end{array}$} \\
\hline Fuel mix for NG exploitation & & \\
\hline Leakage in NG exploitation stage & & \multirow{3}{*}[34]{} \\
\hline NG processing efficiency & $94 \%$ & \\
\hline Fuel mix for NG processing & Refined NG (99\%) and electricity (1\%) & \\
\hline (6) NG transportation mode & Pipeline: 100\% (1500 km) & [55] \\
\hline (7) Coal exploitation and processing & & \multirow{3}{*}{$\begin{array}{l}{[34]} \\
{[42]}\end{array}$} \\
\hline Coal exploitation processing efficiency & $95 \%$ & \\
\hline $\begin{array}{l}\text { Fuel mix for coal exploitation } \\
\text { and processing }\end{array}$ & $\begin{array}{l}\text { Raw coal }(73 \%) \text {, electricity }(15 \%) \text {, clean coal }(8 \%) \text {, diesel }(3 \%) \\
\text { and refined NG }(1 \%)\end{array}$ & \\
\hline (8) Coal transportation mode & $\begin{array}{l}\text { Railway: } 49 \%(642 \mathrm{~km}) \text {; waterway: } 26 \%(650 \mathrm{~km}) ; \text { road (long } \\
\text { distance): } 30 \%(310 \mathrm{~km}) \text { and road (short distance): } 100 \%(50 \mathrm{~km})\end{array}$ & {$[42,55]$} \\
\hline (9) Electricity supply mix & $\begin{array}{l}\text { Coal }(67.2 \%), \text { NG }(3 \%) \text {, residual oil }(0.1 \%) \text { and many other } \\
\text { sources }(29.7 \%)\end{array}$ & [55] \\
\hline
\end{tabular}
various energies in the Chinese context are shown in Table A4.

Table A2. Input data for LCA of different end-use energies. 
Table A2. Cont.

\begin{tabular}{clc}
\hline Item & \multicolumn{1}{c}{ Description } & Data Source \\
\hline $\begin{array}{c}\text { (10) Loss ratio during transmission } \\
\text { and distribution }\end{array}$ & $6.67 \%$ & {$[55]$} \\
\hline (11) Electricity supply efficiencies & Coal-based (36.4\%), oil-based (32.0\%), NG-based (45.9\%) & {$[44]$} \\
\hline
\end{tabular}

Note: The sum of the proportions of individual transport modes may exceed $100 \%$. We also assume that these values will not change substantially over the medium-to-long term. Refinery gas is used during the refining of crude oil but is not included in our scope of end-use energies. We therefore assumed that this refining byproduct did not consume additional primary fossil energy but had a GHG emission intensity of $65 \mathrm{~g} / \mathrm{MJ}$.

Table A3. Energy intensity and fuel structure of various transport modes [34].

\begin{tabular}{ccc}
\hline Transport Mode & Energy Intensity $\mathbf{( k J / t o n ~} \mathbf{k m})$ & Fuel Types and Structures \\
\hline Ocean & 23 & Fuel oil (100\%) \\
Railway & 68 & Diesel (41\%), electricity (59\%) \\
Crude oil pipeline & 300 & Fuel oil (50\%), electricity (50\%) \\
NG pipeline & 372 & NG $(90 \%)$, electricity $(10 \%)$ \\
Water transport & 148 & Fuel oil (100\%) \\
Short-distance highway & 1362 & Diesel (72\%), gasoline (28\%) \\
Long-distance highway & 1200 & Diesel (72\%), gasoline $(28 \%)$ \\
\hline
\end{tabular}

Table A4. Data related to direct and indirect GHG emissions for the Chinese context $[39,45]$.

\begin{tabular}{cccccc}
\hline End-Use Energy & $\mathbf{C C}_{\mathbf{j}}(\mathbf{g} / \mathbf{M J})$ & FOR $_{\mathbf{j}}(\mathbf{g} / \mathbf{M J})$ & $\mathbf{C H}_{\mathbf{4}, \text { direct }}(\mathbf{g} / \mathbf{M J})$ & $\mathbf{C H}_{\mathbf{4}, \text { noncomb }}(\mathbf{g} / \mathbf{M J})$ & $\mathbf{N}_{\mathbf{2}} \mathbf{O}_{\text {direct }}(\mathbf{g} / \mathbf{M J})$ \\
\hline Raw coal & 24.08 & 0.9 & 0.001 & 0.406 & 0.001 \\
Raw NG & 15.3 & 0.99 & 0.001 & 0.072 & 0.001 \\
Crude oil & 20 & 0.98 & 0.002 & 0.009 & 0 \\
Clean coal & 25.8 & 0.9 & 0.001 & 0.406 & 0.001 \\
Processed NG & 15.7 & 0.99 & 0.001 & 0.009 & 0.001 \\
Diesel & 20.2 & 0.98 & 0.004 & 0.009 & $0.002 / 0.028^{\mathrm{a}}$ \\
Gasoline & 18.9 & 0.98 & 0.08 & 0.009 & 0.002 \\
Fuel oil & 21.1 & 0.98 & 0.002 & 0.98 & 0 \\
Electricity & - & - & - & - \\
\hline
\end{tabular}

Note: ${ }^{\text {a }}$ The value of 0.002 is for vehicle but 0.028 for others.

\section{References}

1. National Bureau of Statistics of China (NBSC). Annual Possession of Civil Vehicles; NBSC: Beijing, China, 2016. Available online: http:/ / data.stats.gov.cn/easyquery.htm?cn=C01 (accessed on 10 March 2017).

2. China National Petroleum Corporation (CNPC); Economics \& Technology Research Institute. Domestic and Foreign Oil and Gas Industry Development Annual Report 2016; Petroleum Industry Press: Beijing, China, 2016. (In Chinese)

3. China Electric Vehicles Committee of 100 (China EV 100). China EV 100 Annual Research Report; China EV 100: Beijing, China, 2017. (In Chinese)

4. National Bureau of Statistics of China (NBSC). Annual Consumption of Gasoline and Diesel; NBSC: Beijing, China, 2016. Available online: http://data.stats.gov.cn/english/easyquery.htm?cn=C01 (accessed on 18 October 2016).

5. Development Research Center the State Council (DRC). China Natural Gas Development Report 2016; Petroleum Industry Press: Beijing, China, 2016. (In Chinese)

6. Wang, M.; Weber, T. Well-to-Wheels Energy Use and GHG Emissions of Advanced Fuel/Vehicles System-North American Analysis; Argonne National Laboratory: Lemont, IL, USA, 2001.

7. Argonne National Laboratory (ANL). The Greenhouse Gases, Regulated Emissions, and Energy Use in Transportation Model; Argonne National Laboratory: Lemont, IL, USA, 2016. Available online: https:/ /greet.es.anl.gov (accessed on 21 January 2017).

8. Delluchi, M.A. Emissions of GHG from the Use of Transportation Fuels and Electricity-Volume1: Main Text; Center for Transportation Research, Argonne National Laboratory: Lemont, IL, USA, 1991. 
9. Delluchi, M.A. A Lifecycle Emissions Model (LEM): Main Texts; Institute of Transportation Studies, University of California: Davis, CA, USA, 2003.

10. Wallace, J.; Wang, M.; Weber, T.; Finizza, A. GM Study: Well-to-Wheel Energy Use and Greenhouse Gas Emissions of Advanced Fuel/Vehicle Systems-North American Analysis; Technical Report; Argonne National Laboratory: Lemont, IL, USA, 2001.

11. Muratori, M.; Moran, M.J.; Serra, E.; Rizzoni, G. Highly-resolved modeling of personal transportation energy consumption in the United States. Energy 2013, 58, 168-177. [CrossRef]

12. Rahman, M.M.; Canter, C.; Kumar, A. Well-to-wheel life cycle assessment of transportation fuels derived from different North American conventional crudes. Appl. Energy 2015, 156, 159-173. [CrossRef]

13. Concawe; EUCAR; EC Joint Research Centre. Well-to-Wheels Analysis of Future Automotive Fuels and Powertrains in the European Context. 2007. Available online: https:/ /iet.jrc.ec.europa.eu/about-jec/sites/iet. jrc.ec.europa.eu.about-jec/files/documents/wtw3_wtw_report_eurformat.pdf (accessed on 8 December 2016).

14. Torchio, M.F.; Santarelli, M.G. Energy, environmental and economic comparison of different powertrain/fuel options using well-to-wheels assessment, energy and external costs_European market analysis. Energy 2010, 35, 4156-4171. [CrossRef]

15. Patil, V.; Shastry, V.; Himabindu, M. Life cycle analysis of energy and greenhouse gas emissions of automotive fuels in India: Part 2-Well-to-wheels analysis. Energy 2016, 96, 699-712. [CrossRef]

16. Orsi, F.; Muratori, M.; Rocco, M. A multi-dimensional well-to-wheels analysis of passenger vehicles in different regions: Primary energy consumption, $\mathrm{CO}_{2}$ emissions, and economic cost. Appl. Energy 2016, 169, 197-209. [CrossRef]

17. Choi, W.; Song, H.H. Well-to-wheel analysis on greenhouse gas emission and energy use with natural gas in Korea. Int. J. Life Cycle Assess. 2014, 19, 850-860. [CrossRef]

18. Ou, X.; Yan, X.; Zhang, X. Using coal for transportation in China: Life cycle GHG of coal-based fuel and electric vehicle, and policy implications. Int. J. Greenh. Gas Control 2010, 4, 878-887. [CrossRef]

19. Ke, W.; Zhang, S.; He, X. Well-to-wheels energy consumption and emissions of electric vehicles: Mid-term implications from real-world features and air pollution control progress. Appl. Energy 2017, 188, 367-377. [CrossRef]

20. Zhang, L.; Huang, Z. Analysis of life cycle energy consumption and greenhouse gases emission of coal-based vehicle fuels. J. China Coal Soc. 2006, 31, 662-665. (In Chinese)

21. Wang, L.; Xie, X.; Huang, Z. Life Cycle Energy Use and GHG Emissions Assessment for Coal Derived DME and FTD. Coal Chem. Ind. 2016, 44, 12-15. (In Chinese)

22. Ou, X.; Zhang, X. Life-Cycle Analyses of Energy Consumption and GHG Emissions of Natural Gas-Based Alternative Vehicle Fuels in China. J. Energy 2013, 2013, 268263. [CrossRef]

23. Ou, X.; Zhang, X.; Zhang, X. Life Cycle GHG of NG-Based Fuel and Electric Vehicle in China. Energies 2013, 6, 2644-2662. [CrossRef]

24. Zhou, G.; Ou, X.; Zhang, X. Development of electric vehicles use in China: A study from the perspective of life-cycle energy consumption and greenhouse gas emissions. Energy Policy 2013, 59, 875-884. [CrossRef]

25. Canals Casals, L.; Martinez-Laserna, E.; Amante García, B.; Nieto, N. Sustainability analysis of the electric vehicle use in Europe for $\mathrm{CO}_{2}$ emissions reduction. J. Clean. Prod. 2016, 127, 425-437. [CrossRef]

26. Requia, W.J.; Adams, M.D.; Arain, A.; Koutrakis, P.; Ferguson, M. Carbon dioxide emissions of plug-in hybrid electric vehicles: A life-cycle analysis in eight Canadian cities. Renew. Sustain. Energy Rev. 2017, 78, 1390-1396. [CrossRef]

27. Tamayao, M.M.; Michalek, J.J.; Hendrickson, C.; Azevedo, I.M.L. Regional variability and uncertainty of electric vehicle life cycle $\mathrm{CO}_{2}$ emissions across the United States. Environ. Sci. Technol. 2015, 49, 8844-8855. [CrossRef] [PubMed]

28. Granovskii, M.; Dincer, I.; Rosen, M.A. Life cycle assessment of hydrogen fuel cell and gasoline vehicles. Int. J. Hydrog. Energy 2006, 31, 337-352. [CrossRef]

29. Toyota (Toyota Motor Corporation). Well-to-Wheel Analysis of Greenhouse Gas Emissions of Automotive Fuels in the Japanese Context; Toyota Motor Corporation: Tokyo, Japan, 2004; Available online: http:/ / www.mizuhoir.co.jp/english/ (accessed on 26 February 2017).

30. Van Mierlo, J.; Messagie, M.; Rangaraju, S. Comparative environmental assessment of alternative fueled vehicles using a life cycle assessment. Transp. Res. Procedia 2017, 25, 3435-3445. [CrossRef]

31. Zhang, Q. Research on the Path Selection of Alternative Automobile Fuels Based on the LCA Theory; Tianjin University: Tianjin, China, 2012. 
32. Shen, W.; Han, W.J.; Chock, D.; Chai, Q.H.; Zhang, A.L. Well-to-wheels life cycle analysis of alternative fuels and vehicle technologies in China. Energy Policy 2012, 49, 296-307. [CrossRef]

33. Ou, X.; Yan, X.; Zhang, X. Life cycle analysis on energy consumption and GHG emission intensities of alternative vehicle fuels in China. Appl. Energy 2012, 90, 218-224. [CrossRef]

34. Li, X.; Ou, X.; Zhang, X.; Zhang, Q.; Zhang, X. Life cycle fossil energy consumption and greenhouse gas emission intensity of dominant secondary energy pathways of China in 2010. Energy 2013, 50, 15-23. [CrossRef]

35. Ou, X.; Yan, X.; Zhang, X. Life-cycle energy consumption and greenhouse gas emissions for electricity generation and supply in China. Appl. Energy 2011, 88, 289-297. [CrossRef]

36. Ou, X.; Zhang, X.; Chang, S. Energy consumption and GHG emissions of six biofuel pathways by LCA in (the) People's Republic of China. Appl. Energy 2009, 86, 197-208. [CrossRef]

37. Ou, X.; Zhang, X.; Chang, S. Alternative fuel buses currently in use in China: Life-cycle fossil energy use, GHG emissions and policy recommendations. Energy Policy 2010, 38, 406-418. [CrossRef]

38. Ou, X.; Zhang, X.; Chang, S. Scenario analysis on alternative fuel/vehicle for China's future road transport: Life-cycle energy demand and GHG emissions. Energy Policy 2010, 38, 3943-3956. [CrossRef]

39. Intergovernmental Panel on Climate Change (IPCC). IPCC Guidelines for National GHG Inventories; IPCC: Geneva, Switzerland, 2006; Available online: http:/ /www.ipcc-nggip.iges.or.jp/public/2006gl (accessed on 15 September 2015).

40. Intergovernmental Panel on Climate Change (IPCC). IPCC Fourth Assessment Report: Climate Change 2007; IPCC: Geneva, Switzerland, 2007.

41. Ou, X.M.; Zhang, X.L. Life Cycle Analysis of the Automotive Energy Pathways in China; Tsinghua University Press: Beijing, China, 2011. (In Chinese)

42. Bureau of Statistics of China. China Energy Statistical Yearbook; China Statistics Press: Beijing, China, 2016.

43. Weisser, D. A guide to life cycle greenhouse gas (GHG) emissions from electric supply technologies. Energy 2007, 32, 1543-1559. [CrossRef]

44. China Academy of Engineering (CAE). Greenhouse Gas Emissions of Different Power Energy in China; Atomic Energy Press: Beijing, China, 2015. (In Chinese)

45. Intergovernmental Panel on Climate Change (IPCC). Carbon Dioxide Capture and Storage: IPCC Special Report; IPCC: Geneva, Switzerland, 2005.

46. Shen, W. Well-to-Wheel Analysis on Energy Use, GHG Emissions and Cost of Vehicle Fuels in Future China; Tsinghua University: Beijing, China, 2007. (In Chinese)

47. Jaramillo, P.; Samaras, C.; Wakeley, H.; Meisterling, K. Greenhouse gas implications of using coal for transportation: Life cycle assessment of coal-to-liquids, plug-in hybrids, and hydrogen pathways. Energy Policy 2009, 37, 2689-2695. [CrossRef]

48. Wang, R. Fuel-Cycle Assessment of Energy and Environmental Impacts from Electric Vehicles and Natural Gas Vehicles; Tsinghua University: Beijing, China, 2015. (In Chinese)

49. Chinese Electricity Council (CEC). China Electric Power Statistics Analysis 2015; CEC: Beijing, China, 2016. (In Chinese)

50. Qiao, Q.; Zhao, F.; Liu, Z.; Jiang, S.; Hao, H. Cradle-to-gate greenhouse gas emissions of battery electric and internal combustion engine vehicles in China. Appl. Energy 2017, 204, 1399-1411. [CrossRef]

51. Qiao, Q.; Zhao, F.; Liu, Z.; Jiang, S.; Hao, H. Comparative Study on Life Cycle $\mathrm{CO}_{2}$, Emissions from the Production of Electric and Conventional Vehicles in China. Energy Procedia 2017, 105, 3584-3595. [CrossRef]

52. Hao, H.; Mu, Z.; Jiang, S.; Liu, Z.; Zhao, F. GHG Emissions from the production of lithium-ion batteries for electric vehicles in China. Sustainability 2017, 9, 504. [CrossRef]

53. Hao, H.; Qiao, Q.; Liu, Z.; Zhao, F. Impact of recycling on energy consumption and greenhouse gas emissions from electric vehicle production: The China 2025 case. Resour. Conserv. Recycl. 2017, 122, 114-125. [CrossRef]

54. Zah, R.; Böni, H.; Gauch, M.; Hischier, R.; Lehmann, M.; Wäger, P. Life Cycle Assessment of Energy Products: Environmental Assessment of Biofuels; EMPA: Bern, Switzerland, 2007.

55. China Traffic and Transportation Association (CTTA). Year Book of China Transportation and Communications 2014; China Communications Press: Beijing, China, 2016.

(C) 2017 by the authors. Licensee MDPI, Basel, Switzerland. This article is an open access article distributed under the terms and conditions of the Creative Commons Attribution (CC BY) license (http:/ / creativecommons.org/licenses/by/4.0/). 